\title{
iिखा
}

Instituto de Pesquisas Energéticas e Nucleares

Autarquia associada à Universidade de São Paulo

\section{RENATURAÇÃO EM ALTAS PRESSÕES HIDROSTÁTICAS DE PROTEÍNAS RECOMBINANTES AGREGADAS EM CORPOS DE INCLUSÃO PRODUZIDOS}

EM ESCHERICHIA COII

\author{
Keli Nunes Balduino
}

Dissertação apresentada como parte dos requisitos para obtenção do grau de mestre em ciências na área de Tecnologia Nuclear - Aplicações.

Orientadora: Dra. Lígia Ely Morganti Ferreira Dias

São Paulo 2009 


\title{
सिखा
}

Instituto de Pesquisas Energéticas e Nucleares

Autarquia associada à Universidade de São Paulo

\section{RENATURAÇÃO EM ALTAS PRESSÕES HIDROSTÁTICAS DE PROTEÍNAS RECOMBINANTES AGREGADAS EM CORPOS DE INCLUSÃO PRODUZIDOS}

EM ESCHERICHIA Coli

\author{
Keli Nunes Balduino
}

Dissertação apresentada como parte dos requisitos para obtenção do grau de mestre em ciências na área de Tecnologia Nuclear - Aplicações.

Orientadora: Dra. Lígia Ely Morganti Ferreira Dias

São Paulo 2009 


\section{Dedicatória}

Dedico este trabalho ao meu marido Otávio, por toda a dedicação e amor investidos em mim durante todos esses 9 anos juntos e por dividir comigo cada

momento desse trabalho, e aos meus pais Cleuza e João por todo apoio que me deram até hoje. 


\section{Agradecimentos especiais}

Agradeço primeiramente a Deus, por me permitir cumprir mais essa etapa em minha vida e sonhar com as próximas que virão.

Agradeço aos meus pais, Cleuza e João por todo amor e educação que me deram pra que pudesse seguir sempre em frente com cabeça erguida e consciência limpa.

Agradeço a toda minha família, especialmente à Dany, Tata, Lua e Sofia, por trazer luz e ser a alegria da minha vida e por todos os momentos divididos.

Agradeço a minha orientadora Dra. Ligia Morganti pela paciência e dedicação e por tudo que me ensinou.

Agradeço a todos os amigos de trabalho, Danielle, Maria Eugênia, Bruno, Karina, Larissa, Juliana do Butantan especialmente à Natália, pela amizade, diversão e trabalho em equipe, também à Danielle e Laura pelo trabalho compartilhado, conversas e amizade. Agradeço também a Rosa e Johnny por toda ajuda.

Agradeço ao Dr. Álvaro Prieto do Instituto Butantan pela NXH8 e por valiosos ensinamentos, também ao Dr. Geraldo Magalhães também do Instituto Butantan pela Naterina 2 e à Dra Mônica e Fernanda Bruni, do CAT-CEPID pelo ensaio de microscopia intravital.

Agradeço ao Dr. Patrick do IPEN pela Bothropstoxina 1 e por todo o conhecimento compartilhado, além da paciência de esperar os experimentos ficarem prontos.

Agradeço à Dra. Regina Afonso do IPEN, pela ajuda em muitos experimentos e por me acompanhar nas viagens para Campinas.

Agradeço a todos os demais funcionários e colegas do IPEN.

Agradeço a todos os amigos da UNESP/Rio Claro, pelas lembranças maravilhosas desses tempos, que ainda me acompanham, especialmente à Luana 
e Mazzeo, pela amizade, companhia e paciência, principalmente nos primeiros meses que estive aqui, numa vida completamente nova.

Agradeço à CNPq pelo financiamento através da bolsa de mestrado e à FAPESP pelo financiamento do projeto na qual meu trabalho se inseriu.

Novamente e finalmente agradeço aos meus desafetos, pois ainda me tornam mais forte a cada dia. 


\title{
RENATURAÇÃO EM ALTAS PRESSÕES HIDROSTÁTICAS DE PROTEÍNAS RECOMBINANTES AGREGADAS EM CORPOS DE INCLUSÃO PRODUZIDOS EM ESCHERICHIA COIi
}

\author{
Keli Nunes Balduino
}

\section{Resumo}

A expressão de proteínas na forma de corpos de inclusão em bactérias é uma alternativa muito interessante para obtenção de proteínas recombinantes. No entanto, a agregação é uma dificuldade frequentemente encontrada durante a renaturação dessas proteínas. Altas pressões hidrostáticas são capazes de solubilizar os corpos de inclusão na presença de baixas concentrações de reagentes desnaturantes, favorecendo a renaturação protéica com alto rendimento e redução de custos. $O$ presente trabalho tem como objetivo a renaturação de proteínas recombinantes expressas em Escherichia coli sob a forma de corpos de inclusão usando altas pressões hidrostáticas. Três toxinas, todas apresentando cinco ou mais pontes dissulfídicas foram estudadas: NXH8, Naterina 2 e Bothropstoxina 1. Suspensões dos corpos de inclusão das três proteínas foram pressurizadas em 2000 bares de pressão durante 16 horas. Os tampões de renaturação foram otimizados para as três proteínas. $O$ tampão utilizado no processo de renaturação da NXH8 foi Tris $\mathrm{HCl} 50 \mathrm{mM}$, pH 9,0 com proporção de 1GSH:4GSSG em concentração de $6 \mathrm{mM}$ e $2 \mathrm{M} \mathrm{GdnHCl}$. Foram utilizados corpos de inclusão em D.O.( $\left(A_{600 n m}\right)$ de 0,5. Após o processo de renaturação foi realizada diálise em pH 7,0. O rendimento final de recuperação de NXH8 solúvel foi de $40 \%$, sendo obtidos 28,6 mg/L de meio de cultura. A renaturação de Bothropstoxina 1 foi obtida em tampão de renaturação Tris $\mathrm{HCl} 50 \mathrm{mM}$ pH 7,5 na proporção de 2 GSH:3 GSSG em concentração de $3 \mathrm{mM}$ e $1 \mathrm{M}$ GdnHCl. Utilizamos uma 
suspensão com D.O. $\left(A_{600 n m}\right)$ de 0,5 . O rendimento final de recuperação de Bothropstoxina 1 renaturada foi de $32 \%$, obtendo-se $9,2 \mathrm{mg} / \mathrm{L}$ de meio de cultura. A renaturação de Naterina 2 foi obtida em tampão de renaturação com 20 mM de Tris $\mathrm{HCl}$ pH 9,0 na proporção de 2 GSH:3 GSSG e concentração de $10 \mathrm{mM}$ e $1 \mathrm{M}$ $\mathrm{GdnHCl}$ e corpos de inclusão na D.O. $\left(A_{600 \mathrm{~nm}}\right)$ de 6,0. Foram obtidas $3,7 \mathrm{mg}$ de Nateria 2 renaturada / $L$ de meio de cultura (20\% de recuperação a partir dos corpos de inclusão). O rendimento da Naterina 2 renaturada foi de $20 \%$. Para a análise e a comprovação da eficácia do processo de renaturação sob pressão foram utilizadas as técnicas de SDS-PAGE, western blot, microscopia eletrônica de varredura, ensaios biológicos in vivo e in vitro e estruturais. As análises físicoquímicas realizadas em NXH8 não mostraram nenhuma comprovação da sua renaturação. $O$ ensaio in vivo realizado com a Naterina 2 mostrou uma leve atividade de contração de vênulas, indicando que ela esteja em sua conformação correta. Os ensaios in vitro com a Bothropstoxina 1 mostraram uma atividade citotóxica dose-dependente em células musculares. 


\title{
REFOLDING IN HIGH HIDROSTATIC PRESSURE OF RECOMBINANT PROTEINS FROM INCLUSION BODIES IN ESCHERICHIA COIi
}

\author{
Keli Nunes Balduino
}

\section{Abstract}

The expression of proteins as inclusion bodies in bacteria is a widely used alternative for production of recombinante protein. However, the aggregation is a problem often encountered during refolding of these proteins. High hydrostatic pressure are able to solubilize the inclusion bodies in the presence of low concentrations of denaturant reagents, encouraging refolding protein with high efficiency and reduce costs. This work aims to refolding of recombinant proteins expressed in Escherichia coli from inclusion bodies using high hydrostatic pressure. Three toxins, all featuring five or more disulfide bonds were studied: NXH8, Natterin 2 and Bothropstoxin 1. Suspensions of inclusion bodies of the three proteins were pressurized to 2000 bars for 16 hours. The buffers were optimized for refolding of the three proteins. The buffer used in the refolding of NXH8 was $50 \mathrm{mM}$ Tris $\mathrm{HCl}, \mathrm{pH} 9.0$ with proportion of 1GSH: 4GSSG at a concentration of $6 \mathrm{mM}$ and $2 \mathrm{M} \mathrm{GdnHCl}$. Inclusion bodies were used in O.D. $\left(A_{600 n m}\right)$ of 0.5 . After refolding process, dialysis was performed at $\mathrm{pH}$ 7.0. The final yield of obtaining soluble NXH8 was $40 \%(28,6 \mathrm{mg}$ of soluble $\mathrm{NXH} 8 / \mathrm{L}$ of culture medium). The refolding of Bothropstoxin 1 was obtained in refolding buffer of Tris $\mathrm{HCl} 50 \mathrm{mM}, \mathrm{pH}$ 7,5 with proportion of $2 \mathrm{GSH}$ : GSSG 3 and concentration of $3 \mathrm{mM}$ and $1 \mathrm{M} \mathrm{GdnHCl}$. Use with a suspension of O.D. $\left(A_{600 \mathrm{~nm}}\right)$ of 0.5 . The final yield of recovery of Bothropstoxin 1 refolded was $32 \%(9,2 \mathrm{mg}$ of refolded Bothropstoxin $1 / \mathrm{L}$ of culture medium). The refolding of Natterin 2 was performed in the refolding buffer: $20 \mathrm{mM}$ Tris $\mathrm{HCl} \mathrm{pH} 9.0$ at a ratio of $2 \mathrm{GSH}$ : 3GSSG and concentration of 10 $\mathrm{mM}$ and $1 \mathrm{M} \mathrm{GdnHCl}$ and inclusion bodies O.D. $\left(A_{600 \mathrm{~nm}}\right)$ of 6.0. The yield of 
Natterin 2 refolded was 20\% (3,7 mg/L of culture medium). Physico-chemical and biological analysis were performed by SDS-PAGE, western blot, scanning electron microscopy, biological tests in vivo and in vitro and structural. The analysis conducted in NXH8 did not show any evidence of refolding. An activity of contraction of venules was show by the in vivo test indicating a correct conformation of Natterin 2. Tests in vitro with Bothropstoxin 1 showed a dosedependent cytotoxic activity in muscle cells. 


\section{Sumário}

\begin{tabular}{|c|}
\hline Excluído: 3 \\
\hline Excluído: 4 \\
\hline Excluído: 6 \\
\hline Excluído: 8 \\
\hline Excluído: 11 \\
\hline Excluído: 19 \\
\hline Excluído: 20 \\
\hline Excluído: 21 \\
\hline Excluído: 22 \\
\hline Excluído: 24 \\
\hline Excluído: 25 \\
\hline Excluído: 25 \\
\hline Excluído: 25 \\
\hline Excluído: 26 \\
\hline Excluído: 27 \\
\hline Excluído: 28 \\
\hline Excluído: 29 \\
\hline Excluído: 29 \\
\hline Excluído: 30 \\
\hline Excluído: 31 \\
\hline Excluído: 32 \\
\hline Excluído: 32 \\
\hline Excluído: 32 \\
\hline Excluído: 33 \\
\hline Excluído: 33 \\
\hline Excluído: 33 \\
\hline Excluído: 34 \\
\hline Excluído: 34 \\
\hline Excluído: 35 \\
\hline Excluído: 36 \\
\hline Excluído: 36 \\
\hline Excluído: 36 \\
\hline Excluído: 37 \\
\hline Excluído: 38 \\
\hline Excluído: 38 \\
\hline Excluído: 38 \\
\hline Excluído: 41 \\
\hline Excluído: 46 \\
\hline Excluído: 46 \\
\hline Excluído: 49 \\
\hline Excluído: 52 \\
\hline Excluído: 52 \\
\hline Excluído: 54 \\
\hline Excluído: 57 \\
\hline Excluído: 63 \\
\hline
\end{tabular}

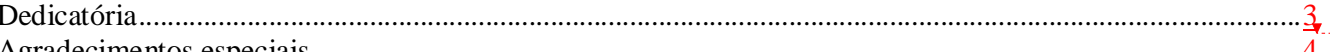

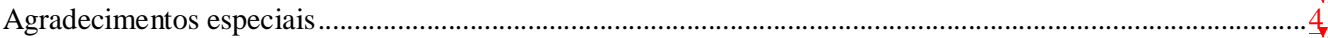

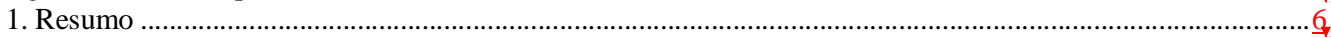

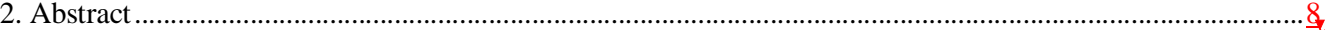

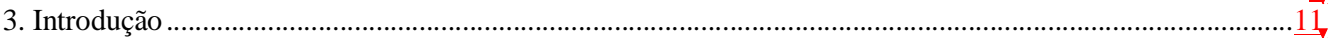

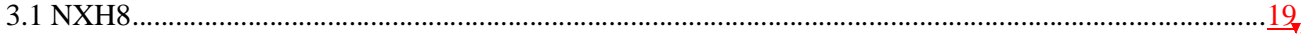

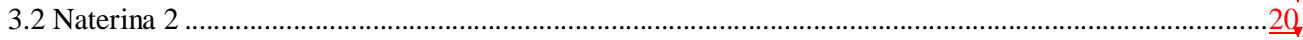

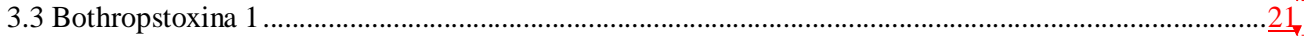

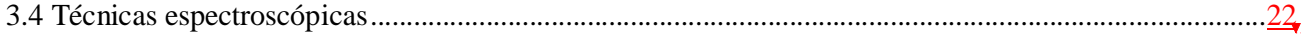

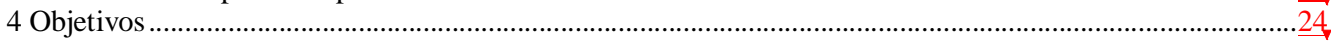

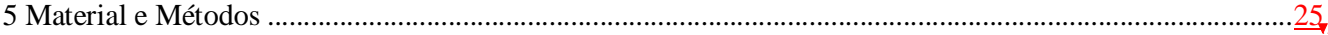

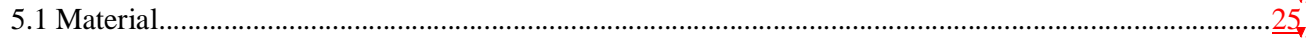

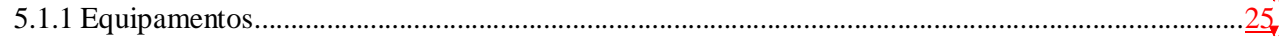

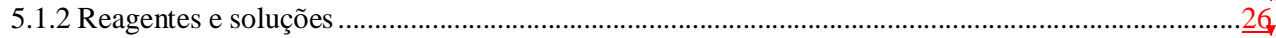

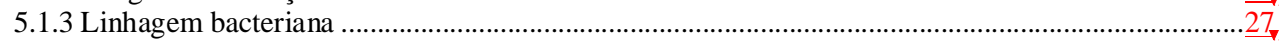

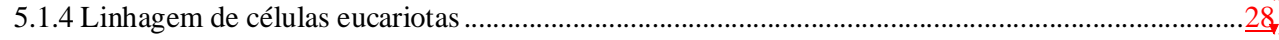

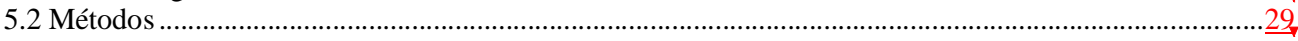

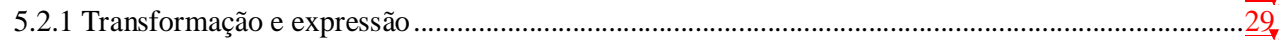

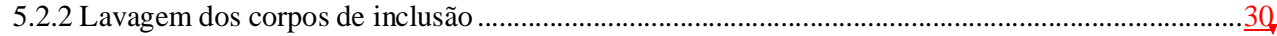

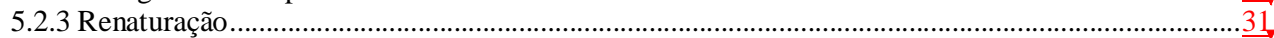

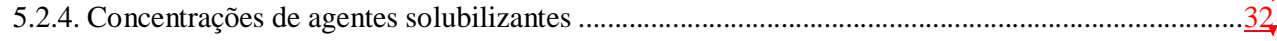

5.2.5 Aditivos, pH e D.Os. dos corpos de inclusão ..........................................................................

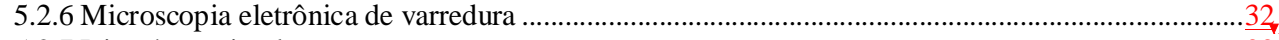

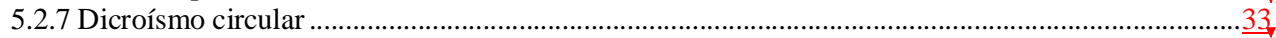

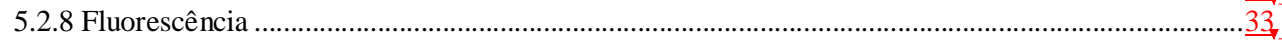

5.2.9 SDS-PAGE, quantificação de proteínas totais e HPLC ….......................................................33.

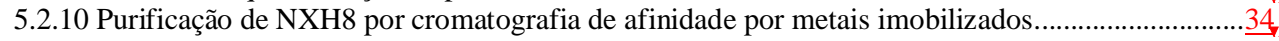

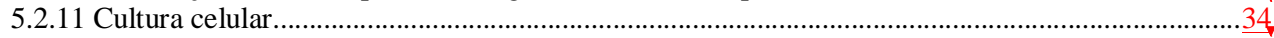

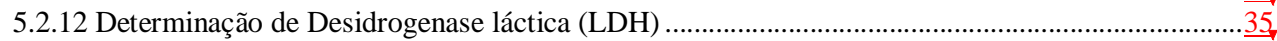

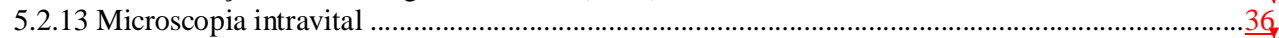

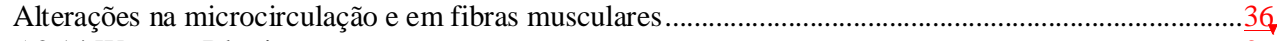

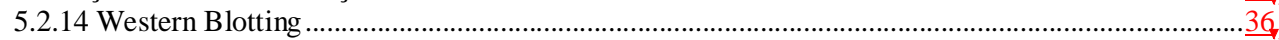

5.2.15 Tabela de conversão de pressão..........................................................................................

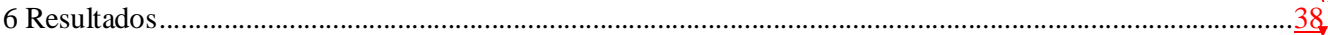

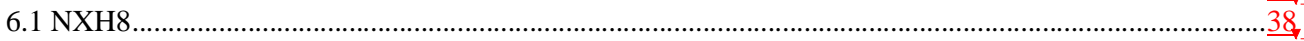

6.1.1 Determinação das condições de pressurização ........................................................................38

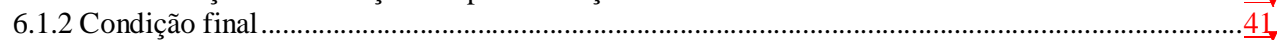

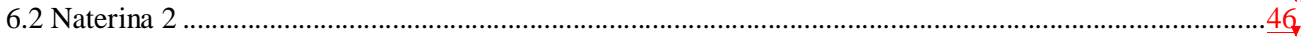

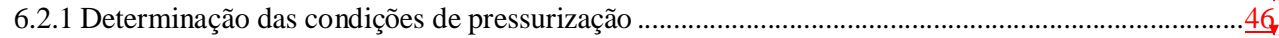

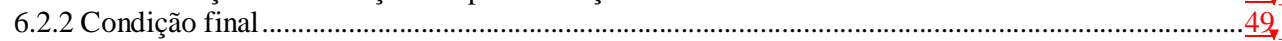

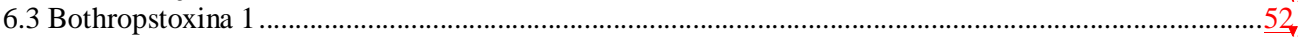

6.3.1 Determinação das condições de pressurização ..........................................................................52

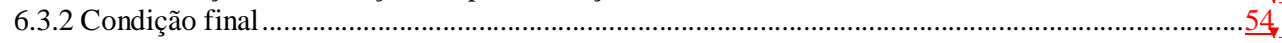

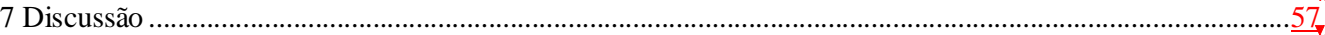

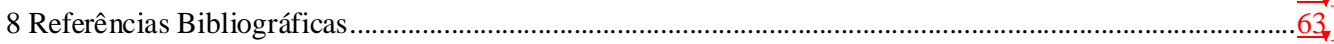




\section{Introdução}

A expressão de proteínas em microrganimos transformados tem sido uma técnica fundamental no desenvolvimento da pesquisa biológica moderna (Qoronfleh e cols., 2007). Há um grande número de opções de microorganismos hospedeiros para expressão de proteínas, entre eles, a bactéria $E$. coli é a mais conveniente e frequentemente utilizada (Arakawa e cols., 2003) por ter sido o microorganismo mais estudado e por razões de velocidade de multiplicação celular e simplicidade (Middelberg, 2002). No entanto, a expressão em E. coli frequentemente leva à produção de proteínas agregadas e insolúveis expressas em corpos de inclusão (Lefebvre e cols.,2004) no citoplasma bacteriano (Clark, 2001) e representa um sério obstáculo para a produção eficiente de proteínas recombinantes (St John e cols., 1999).

Corpos de inclusão são agregados densos de polipeptídeos sem conformação ou com conformação parcial. Eles são formados intracelularmente pela agregação característica de proteínas e pela incapacidade das células hospedeiras em produzir polipeptídios solúveis e em sua conformação correta (Bowden e cols., 1991; Middelberg, 2002). Além disso, a maquinaria das células procarióticas é incapaz de processar os altos níveis de expressão que ocorrem durante a produção de proteínas recombinantes típicas, resultando na formação de corpos de inclusão. Sua formação é comum, frequentemente inevitável (Qoronfleh e cols., 2007) e pode ser considerada como um equilíbrio dinâmico entre a adição e remoção de proteínas dos agregados em sua conformação parcial, com o equilíbrio geralmente tendendo para o estado insolúvel. A agregação é determinada pela ação conjunta dos sistemas de processamento celular e do equilíbrio termodinâmico que causa a auto-associação dos polipeptídios. Corpos de inclusão estão normalmente localizados no citoplasma, 
embora as proteínas secretadas também possam formar corpos de inclusão no espaço periplásmico bacteriano.

Apesar da produção de corpos de inclusão ser, de modo geral, considerada indesejável, sua formação pode ser vantajosa. Entre os benefícios estão: altos níveis de expressão, chegando a mais de $30 \%$ do total de proteínas celulares em alguns casos, baixo custo, expressão e homogeneidade da proteína alvo, resistência proteolítica e como resultado, baixos níveis de degradação das proteínas expressas. Se a proteína de interesse for tóxica para a célula hospedeira, então, a expressão em corpos de inclusão pode ser a única alternativa viável (Clark, 2001; Singh e Panda, 2005). Além disso, o isolamento e a possibilidade de purificação para obtenção de corpos de inclusão com menos contaminantes bacterianos a partir das células hospedeiras é bastante simples, devido à diferença de densidade, quando comparada com a maior parte dos contaminantes celulares (Singh e Panda, 2005). Claramente, essas propriedades somente podem ser consideradas benefícios se as proteínas de interesse puderem ser renaturadas para obter proteínas nativas com altos rendimentos (Qoronfleh e cols., 2007).

Há três passos importantes na recuperação de proteínas nativas a partir de corpos de inclusão: isolamento e lavagem dos corpos de inclusão; solubilização dos agregados e renaturação das proteínas solubilizadas (Clark, 2001; Middelberg, 2002). Embora a eficiência dos dois primeiros passos normalmente seja alta, a eficiência da renaturação pode ser limitada pelo acúmulo proteínas não nativas, bem como de agregados (Clark, 2001).

O método mais comum para o isolamento dos corpos de inclusão envolve a ruptura celular química ou mecânica (Rudolph e Lilie, 1996), seguida por centrifugação diferencial para separar os corpos de inclusão densos e insolúveis dos componentes bacterianos de membrana e contaminantes solúveis. Existem evidências de que a alta concentração de contaminantes presentes na preparação dos corpos de inclusão pode diminuir significativamente o rendimento de renaturação das proteínas recombinantes (Middelberg, 2002).

A produção de proteínas recombinantes a partir de corpos de inclusão é frequentemente dificultada pela agregação de proteínas, o qual compete com a própria renaturação e leva à baixa produção de proteínas biologicamente funcionais. O correto enovelamento envolve reações intramoleculares não 
covalentes e é necessário para o funcionamento das funções biológicas das proteínas, enquanto a agregação é uma reação intermolecular (Desai e cols., 2006).

Corpos de inclusão devem ser solubilizados e renaturados a fim de adquirir uma conformação nativa. Infelizmente não há um método de renaturação ou tampão único para todas as proteínas. A renaturação de corpos de inclusão frequentemente requer um extensivo processo de tentativa e erro (Arakawa e cols., 2003).

Os processos clássicos de renaturação de proteínas a partir de agregados em corpos de inclusão utilizam agentes desnaturantes químicos fortes em altas concentrações, o que resulta em uma desnaturação completa das moléculas de proteína. Os agentes mais comumente utilizados para solubilização dos corpos de inclusão ou proteínas agregadas são hidrocloreto de guanidina ( $\mathrm{GdnHCl}$ ) e uréia (Clark, 2001). Uréia e GdnHCl levam à formação de estruturas protéicas flexíveis e desordenadas. Quando níveis elevados destes agentes desnaturantes são utilizados, a solubilização pode ser completa com a total perda de estrutura da proteína e pela ruptura de interações intramoleculares. Para proteínas com aminoácidos cisteína, pontes dissulfídicas nativas podem se formar mesmo na conformação incorreta, na presença de desnaturantes. Detergentes iônicos também foram descritos para a solubilização de agregados por serem fortes dispersores com formação de estruturas monomoleculares devido à forte repulsão eletrostática do complexo detergente-proteína, o qual pode assumir estrutura secundária não nativa (Arakawa e cols., 2003).

Uma vez solúveis e desnaturadas, as proteínas são primeiramente diluídas e então renaturadas pela remoção do agente caotrópico por diálise, diluição adicional ou ainda outro processo. O passo de renaturação, no entanto, é difícil e depende fortemente das condições de renaturação. Por exemplo, condições de par redox, $\mathrm{pH}$, taxas de diálise e concentração protéica devem ser empiricamente otimizados para cada proteína. Além disso, a agregação geralmente é favorecida sobre a renaturação em concentrações protéicas altas. Então, para se estabelecer condições que levem a rendimentos aceitáveis de proteínas renaturadas freqüentemente se utiliza concentrações protéicas muito baixas (10 a $100 \mu \mathrm{g} / \mathrm{ml}$ ) para que a retirada do agente caotrópico possa ocorrer sem reagregação (Clark, 1998; Vincentelli e cols., 2004). Frequentemente, após pesquisa extensiva, os 
rendimentos de renaturação continuam muito baixos. Além disso, baixas concentrações de proteína necessárias para obtenção de rendimentos de renaturação aceitáveis levam a grandes volumes de processamento e requerem grandes quantidades de agentes caotrópicos corrosivos e tóxicos com altos custos de aquisição e descarte (Clark, 2001).

Os agregados nos corpos de inclusão contêm altos níveis de estrutura de folhas beta intermoleculares não nativas. As unidades de polipeptídeos nos agregados podem ser mantidas juntas por uma variedade de forças como ligações de hidrogênio e interações hidrofóbicas e eletrostáticas (Lefebvre e cols., 2004). O citoplasma bacteriano é um meio redutor e devido a este fato quando as proteínas agregam em corpos de inclusão, as pontes dissulfeto potenciais permanecem como cisteínas livres. Quando os corpos de inclusão são extraídos e purificados das células, as cisteínas são oxidadas, formando pontes dissulfeto inter e intramoleculares (Rudolph e Lilie, 1996; Clark, 2001; Singh e Panda, 2005; Qoronfleh e cols., 2007).

As proteínas em corpos de inclusão são constituídas de moléculas, densamente empacotadas compostas de intermediários de proteínas com conformação parcial e são compostos principalmente de agregados de tipos simples de polipeptídeos (Speed e cols., 1996). Já foi comprovada a presença de estruturas secundárias nativas em proteínas nos corpos de inclusão (Bowden e cols., 1991; Ami e cols., 2006). Além disso, dados recentes indicam a presença de certa porcentagem de proteínas apresentando estruturas terciárias com conformação nativa, concomitantemente com intermediários de conformação inadequada (De Groot e Ventura, 2006; Garcia-Fruitos e cols., 2007), fato de grande importância para a produção de proteínas recombinantes, pois é uma indicação de que as proteínas podem ser liberadas dos corpos de inclusão em um estado funcional, desde que se utilizem condições que desarranjem a rede de contatos inter-moleculares que promovem a estabilidade dos corpos de inclusão sem desnaturarem as estruturas nativas que estão embebidas nestes agregados. Já foi demonstrado também que a solubilização das proteínas em condições brandas que possibilitem a manutenção das estruturas secundária e terciária, favorece a obtenção de estruturas nativas em comparação com a solubilização utilizando altas concentrações de agentes desnaturantes, no qual as proteínas perdem completamente a sua conformação (Patra e cols., 2000). 
A pressão é um parâmetro físico que modula interações proteína-solvente através de mudança de volumes, pois, sob pressão, a derivada da diferença de energia livre de Gibbs entre dois estados é igual à diferença do volume parcial entre os respectivos estados (Zipp e Kauzmann, 1973; Silva e Weber, 1993). Então, pelo princípio de Le Chatelier, a aplicação de alta pressão hidrostática desloca o equilíbrio para estados de menor volume. Em soluções aquosas de proteínas, a perda de cavidades intra e intermoleculares, a hidratação de resíduos hidrofóbicos e a eletroestrição atribuídas a resíduos carregados reduzem o volume do sistema. Assim, estados protéicos contendo espaços de cavidades mínimos, estados com maior exposição de grupos hidrofóbicos ao solvente e estados mais altamente ionizados são favorecidos em altas pressões (Gross e Jaenicke, 1994; Mozhaev e cols., 1996; Randolph e cols., 2002; Cordeiro e cols., 2004; Seefeldt e cols., 2004). Em contraste, a mudança de volume associada com a formação de pontes de hidrogênio é aproximadamente zero, o que faz com que estas ligações sejam insensíveis à ação da pressão (Silva e Weber, 1993; Cordeiro e cols., 2004). Conseqüentemente a pressão afeta o equilíbrio de espécies conformacionais de proteínas entre o estado nativo e desnaturado, bem como formas monoméricas, oligoméricas e agregados (Paladini e Weber, 1981; Cordeiro e cols., 2004). As proteínas agregadas em corpos de inclusão possuem maior volume do que quando na conformação nativa devido à presença de cavidades intermoleculares não expostas à água. As proteínas na sua conformação nativa por sua vez possuem maiores volumes do que suas estruturas desnaturadas devido à presença de cavidades intramoleculares. Conseqüentemente o tratamento sob pressão modula a dissociação de agregados. Pressões moderadas (1000-3000 bar) são frequentemente efetivas para a dissociação de agregados, enquanto pressões maiores (acima de 3000 bar) são tipicamente requeridas para a desnaturação de proteínas (Zipp e Kauzmann, 1973; Randolph e cols., 2002; Cordeiro e cols., 2004; Kim e cols., 2006). Para facilitar a quebra das pontes de hidrogênio entre proteínas nos agregados, a temperatura pode ser elevada nas amostras sob pressão e/ou baixas concentrações, não desnaturantes, de agentes caotrópicos como $\mathrm{GdnHCl}$ podem ser incluídos nas soluções protéicas. A alta pressão também não quebra pontes dissulfídicas que fazem ligações cruzadas covalentes entre agregados de proteínas. Nos casos de polipeptídios contendo aminoácidos cisteína, um par oxido-redutor pode ser 
incluído nas soluções de pressurização de modo a facilitar a quebra das ligações dissulfídicas intermoleculares e formação de pontes dissulfídicas nativas. Após a desagregação induzida por pressão, a quebra e formação de pontes dissulfídicas são necessárias para permitir a formação de moléculas com as menores energias livres. É importante notar que quando as proteínas estão enoveladas em seus estados nativos as pontes dissulfídicas se tornam inacessíveis a reagentes redox exógenos (St John e cols., 2002).

Desagregação e renaturação sob alta pressão é um método fundamentalmente diferente de obtenção de proteínas nativas a partir de agregados insolúveis não nativos, quando comparada aos métodos tradicionais utilizando-se altas concentrações de agentes caotrópicos. Altas pressões dissociam agregados de proteínas sob condições sub-desnaturantes, que favorecem a manutenção das estruturas nativas. Isto permite o início da renaturação a partir de estruturas com menor grau de perturbação do que aquelas induzidas por altas concentrações de agentes caotrópicos. Assim, foi demonstrado que a pressão pode induzir a separação dos agregados e que o subsequente passo de enovelamento pode ser favorecido ainda sob condição de alta pressão (St John e cols., 2001). Em contraste, no caso da utilização das técnicas tradicionais, quando a concentração de agente caotrópico é reduzida, ambas as pontes de hidrogênio e interações hidrofóbicas não nativas se tornam favorecidas, geralmente resultando em reagregação. Por causa dessas propriedades a alta pressão é uma ferramenta útil para dissociação de agregados protéicos em proteínas nativas em uma única etapa, facilitando a preparação de proteínas para estudos estruturais e funcionais e também para aplicações em indústria biotecnológica (Kim e cols., 2006).

Estudos recentes têm mostrado que pressões hidrostáticas moderadas (1000-3000 bar) são uma alternativa atrativa às técnicas tradicionais de desnaturação e diluição, tanto em termos de rendimentos quanto de simplicidade no processo e potencial para aumentar rendimentos de proteínas com conformação nativa e atividade biológica a partir de agregados. Por exemplo, em estudos que utilizaram agregados de hormônio de crescimento recombinante e de lisozima induzidos in vitro por estresse como altas temperaturas e agitação, o processo de renaturação em alta pressão hidrostática levou a altos rendimentos (> $90 \%)$ de proteínas nativas, mesmo utilizando-se altas concentrações protéicas 
(Gorovits e Horowitz, 1998; Foguel e cols., 1999; St John e cols., 1999; St John e cols., 2001; St John e cols., 2002; Lefebvre e cols., 2004; Seefeldt e cols., 2004; Kim e cols., 2006).

Pelo que é de nosso conhecimento, somente quatro publicações descreveram processos de renaturação de proteínas a partir de corpos de inclusão sob alta pressão e entre elas uma publicação do nosso grupo que realizou a renaturação da proteína antiangiogênica endostatina (Chura-Chambi e cols., 2008). Foram descritos ainda os processos de renaturação das proteínas $\beta$ lactamase (St John e cols., 1999) e de membros da família de receptores nucleares (Schoner e cols., 2005). A renaturação de duas fosfatases humanas, contendo 6-11 meias cistinas, ou seja, com pelo menos 3 pontes dissulfeto utilizando-se altas pressões na presença de pares redox foi obtida com altos rendimentos (55\% a $78 \%$ ). Ainda no mesmo artigo foi descrita a renaturação de proteínas de Drosophila melanogaster "Gram-negative bacteria binding proteins" GNPB1, GNPB2 e GNPB3 (Lee e cols., 2006).

Devido ao fato de que cada proteína apresenta características bioquímicas únicas, as condições para melhorar o rendimento de recuperação de cada uma delas é diferente e pode ser identificado sistematicamente usando reagentes especificos. A adição de pequenas moléculas (co-solutos) ao tampão de renaturação para auxiliar na solubilização, facilitar o enovelamento das proteínas ou para impedir a agregação é amplamente descrita para as técnicas de renaturação convencionais (Clark, 1998), mas também já foram descritas para as técnicas de renaturação sob pressão (Lee e cols., 2006). Co-solutos podem ser classificados em dois grupos: 1) aqueles que auxiliam na renaturação por aumentarem as ligações intra-proteína, e 2) o grupo de supressores de agregação, que agem reduzindo a interação entre cadeias laterais das proteínas (Tsumoto e cols., 2003; Bajorunaite e cols., 2007). Surfactantes como Triton X100, Tween 20 e surfaína minimizam as interações hidrofóbicas proteína/proteína, que podem levar à agregação, além de poderem aumentar a sua estabilidade (Arakawa e Timasheff, 1982; Tsumoto e cols., 2004; Kim e cols., 2006). Estes reagentes podem acelerar a formação de uma estrutura compacta mas impedir o rearranjo estrutural. Há a formação do complexo proteína/surfactantes, e o rearranjo estrutural é acompanhado pela dissociação do complexo e redistribuição da molécula de surfactante da parte não exposta para a parte exposta da 
molécula de proteína, sendo assim, eles aceleram a formação do centro hidrofóbico. A estabilidade da proteína pode ser aumentada pela interação hidrofóbica das moléculas surfactantes com resíduos de aminoácidos hidrofóbicos localizados na superfície da molécula. A hidrofobicidade do surfactante afeta o enovelamento das proteínas. Surfactantes com hidrofobicidade média aumentam a taxa de enovelamento e renaturação em diferentes concentrações e os de alta hidrofobicidade podem sob certas condições reduzir a taxa de renaturação (Lu e cols., 2007).

Sacarose, glicose, glicerol e PEG estabilizam as proteínas deslocando o equilíbrio para o estado mais compacto, como no estado nativo. Sais como $\mathrm{NaCl}$ elevam a força iônica do meio, e sua presença pode ser favorável para o caso de proteínas que são sensíveis à baixa força iônica (Arakawa e Timasheff, 1982; Tsumoto e cols., 2004; Kim e cols., 2006). Pequenas moléculas com características polares como açúcares, polióis, certos sais como sulfato de amônia e cloreto de magnésio e certos aminoácidos como glicina e alanina podem ser utilizadas como aditivos, e também podem aumentar a estabilidade das proteínas durante a renaturação (Lee e Timasheff, 1981; Arakawa e Timasheff, 1982, 1982, 1983, 1985; Kopito, 1999; Ohnishi e cols., 1999; Bourot e cols., 2000).

Aminoácidos como L-arginina são classificados tanto como supressores de agregação como agentes solubilizantes (Arakawa e Timasheff, 1982; Tsumoto e cols., 2004; Kim e cols., 2006). Tsumoto e cols, (2004), sugerem que a interação entre os grupos guanidina das cadeias laterais da arginina e dos triptofanos podem ser responsáveis pela supressão de agregação pela arginina. A utilização de arginina pode se mostrar efetiva, não somente na fase inicial da diluição mas também ao longo do processo de renaturação (Bajorunaite e cols., 2007).

$\mathrm{O}$ pH do tampão de renaturação influencia na carga, estabilidade e solubilidade da proteína, na cinética da formação de pontes dissulfeto e pode alterar a reagregação de intermediários durante a renaturação (Pace e cols., 1990). Em geral, para minimizar a agregação durante a renaturação, o pH da solução deve estar entre 1 e 2 unidades de pH abaixo ou acima do ponto isoeléltrico da proteína. Se a proteína contém pontes dissulfeto, o pH ótimo recomendado para renaturação são os alcalinos, entre 7,5 a 10, e devem estar distantes do ponto isoelétrico, favorecendo a formação das pontes dissulfídicas intramoleculares (Pace e cols., 1990; Qoronfleh e cols., 2007). 
A concentração protéica inicial também pode afetar o rendimento final da renaturação. Na maioria das vezes, quanto mais concentrados estão os corpos de inclusão, menor o rendimento de renaturação, pois maior a probabilidade de interação entre moléculas de proteína, formando os agregados (Ersoy e cols., 2009).

Dentre os fatores que podem dificultar a renaturação de proteínas está a presença de pontes dissulfeto. Quanto maior o número de pontes dissulfeto, maior deverá ser a dificuldade de renaturação de uma proteína, devido à formação de pontes intermoleculares, o que leva à agregação e também devido à maiores dificuldades na formação de ligações dissulfeto intramoleculares nativas (St John e cols., 2002).

Formação e dissociação reversíveis de pontes dissulfeto são facilitadas pelo uso de par redox como glutationas. In vitro a razão apropriada de cada um dos agentes oxidante ou redutor do par redox e sua concentração pode variar para cada proteína. No caso da ausência de pontes dissulfeto na proteína nativa, agentes redutores podem ser adicionados para prevenir a formação de pontes não nativas durante o enovelamento (Gilbert, 1995; De Bernardez Clark e cols., 1998).

\subsection{NXH8}

A NXH8 estudada no presente trabalho é uma sequência de cDNA traduzida da toxina encontrada no veneno da cobra coral brasileira Micrurus corallinus. Ela possui o mesmo padrão estrutural observado na família das toxinas de três alças, formadas por 5 folhas $\beta$ pregueadas anti-paralelas que emergem de um centro globular no qual quatro pontes dissulfeto invariáveis estão localizadas (Low e cols., 1976; Zinn-Justin e cols., 1992). Esta proteína tem uma massa molecular teórica de $7.839 \mathrm{Da}$, que é semelhante ao apresentado pelas demais toxinas de três alças da mesma família e um pl de 7,8. A quinta ponte dissulfeto é localizada na ponta da primeira alça, uma característica de vários homólogos de alfa-neurotoxinas longas de serpentes do gênero Bungarus e de neurotoxinas fracas de serpente do gênero Naja (Prieto, 2002). Não são observadas $\alpha$-hélices nesta família de toxinas. As toxinas de serpente com esse padrão estrutural apresentam inúmeras atividades tóxicas diferentes. 
Toxinas de cobras com estrutura de três alças são usualmente classificadas como toxinas de cadeias curtas, que possuem aproximadamente 60 resíduos e quatro pontes dissulfeto. As toxinas de três alças incluem as toxinas curaremiméticas (Drevet e cols., 1997; Ricciardi e cols., 2000).

Estudos detalhados realizados sobre estruturas individuais de toxinas de três alças revelam que elas exibem diferenças marcantes de outras toxinas, indicando que sua conformação pode na verdade acomodar algumas variações (Ricciardi e cols., 2000).

A atividade biológica da NXH8 ainda não foi descrita.

Na figura 1 podemos observar um esquema da estrutura terciária de NXH8.

1

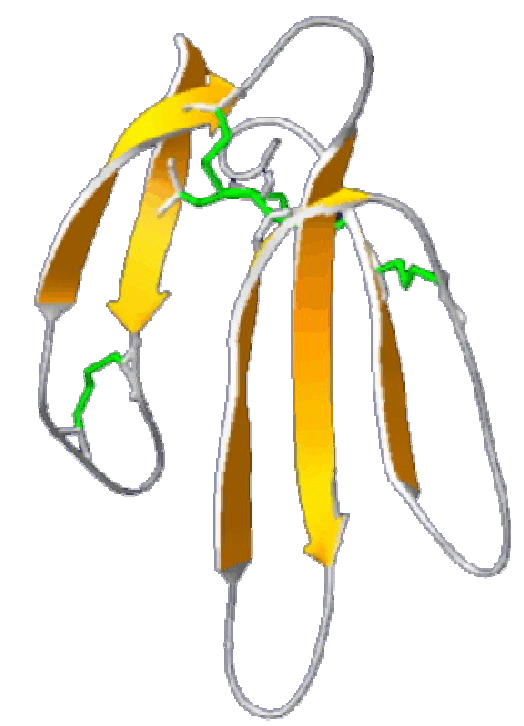

Modelo teórico (1txa) da estrutura tridimensional da proteína NXH8 mostrando as folhas beta representadas em amarelo, e as pontes dissulfídicas representadas em verde. O modelo acima foi gerado a partir do programa PyMOL (Delano, 2002)

\subsection{Naterina 2}

Naterina 2 é uma toxina encontrada no veneno do peixe Thalassoprine nattereri, de nome popular niquim, tem peso molecular de $41.327 \mathrm{Da}$, um pl de 8,9 e possui 12 cisteínas, que formam 6 pontes dissulfeto. Pelo que é de nosso conhecimento ainda não há informações disponíveis sobre as estruturas secundárias e terciárias dessa toxina. É uma proteína pertencente a uma classe de cininogenases (serino endopeptidases), que apresenta estrutura primária 
completamente diferente das proteínas pertencentes às famílias já descritas. Quando isolada do veneno produz uma nocicepção (elevação da percepção de dor) e edema. A atividade de cininogenase das Naterinas tem similaridade com as próprias cininogenases ou outras serino-proteases (Magalhães e cols., 2005).

A Naterina 2 apresenta uma extensão carboxi-terminal de 20 resíduos de aminoácidos que inclui uma região catiônica-hidrofóbica, podendo exercer toxicidade direta, o que explica o papel citotóxico do veneno total de Thalassoprine nattereri para os mioblastos, plaquetas e células endoteliais (Magalhães e cols., 2005).

\subsection{Bothropstoxina 1}

O veneno de numerosas espécies de cobras contém algumas miotoxinas, muitas delas são proteínas básicas como é o caso das fosfolipases A2 (PLA2) (Rosemberg e cols, 1990). As fosfolipases (PLA) apresentam uma vastíssima ocorrência e podem ser divididas em diferentes grupos (Ownby, 1998), elas se caracterizam pela grande quantidade de pontes S-S, variando de 5 a 7 (Giotto, 1996, Carredano e cols., 1998), peso molecular em torno de 14.000 Daltons e dependência de cálcio (John e cols, 1996) para a atividade catalítica. A Bothropstoxina 1 tem grande homologia com fosfolipases A2, apresentando $13.700 \mathrm{Da}$ e 121 aminoácidos isolada do veneno de $B$. jararacussu, seu PI é de 8,2 e possui 7 pontes dissulfeto. Sua estrutura secundária é formada basicamente por alfa-hélices (Cintra e cols., 2001). Na figura 2 podemos observar um esquema da estrutura terciária de Bothropstoxina 1.

A perda da atividade catalítica da Bothropstoxina 1 é causada por uma mutação na qual o ácido aspártico da posição 49 foi substituído por uma Lisina, resultando na incapacidade de ligar o cálcio no sítio ativo (Cintra e cols., 1993, Francis e cols., 1991), impossibilitando a orientação correta do substrato e a conseqüente transferência de hidrogênio da molécula de água para o ácido graxo da posição sn2 do fosfolipídeo (Giotto, 1996). Apesar de desprovidas de atividade catalítica, as fosfolipases $A_{2}$ Lys 49 são altamente miotóxicas. O seu mecanismo de ação, assim como o fator responsável pela sua especificidade tecidual ainda não estão bem claros. Alguns autores sugerem tratar-se de um novo tipo de 
mecanismo citolítico baseado na acilação autocatalítica da toxina (Pedersen, 1995).

De acordo com dados cristalográficos (Giotto, 1996), a Bothropstoxina-1 ocorre na forma de um homodímero.

$\mathrm{Na}$ figura 2 podemos observar um esquema da estrutura quaternária de Bothropstoxina 1, na forma de homodímero.

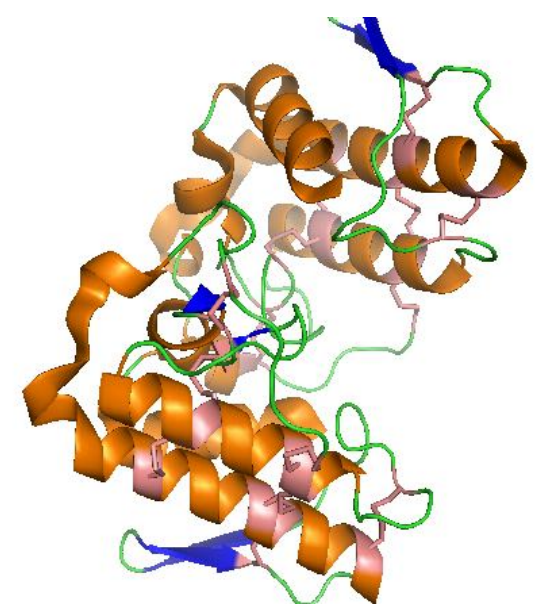

Modelo teórico (2H8l1txa) da estrutura tridimensional da molécula ativa de Bothropstoxina 1 mostrando as folhas beta representadas em azul e pontes dissulfídicas representadas em rosa e alfa-hélices representadas em laranja. O modelo acima foi gerado a partir do programa PyMOL (Delano, 2002)

\subsection{Técnicas espectroscópicas}

Toda técnica espectroscópica baseia-se na detecção e análise de um feixe de radiação eletromagnética vinda da amostra do material que está sendo investigado. Essa radiação pode ser parte de um feixe que incidiu sobre a amostra e foi parcialmente atenuado (espectroscopia de absorção ou transmissão); pode ser um feixe que após incidir sobre a amostra foi espalhado ou difratado (espalhamento); pode ainda ter se originado na própria amostra como resultado de diferentes processos (espectroscopia de emissão) (Ito, 2004). Um conjunto de elementos estruturais secundários define a estrutura de proteínas. Análises experimentais de uma conformação prevista podem ser feitas pela medida de elementos estruturais secundários dos quais a estrutura é composta (Pelton e McLean, 2000). O conhecimento de estruturas de proteínas é fundamental para nosso conhecimento sobre sua função (Yu, 1994). 
A obtenção de grande quantidade de proteínas nativas de interesse médico e comercial até então de difícil produção pode garantir o desenvolvimento de novos produtos, bem como se tornar um novo mercado a ser explorado. A obtenção de proteínas renaturadas em sua conformação nativa a partir de corpos de inclusão com a utilização de altas pressões hidrostáticas é uma ferramenta para este fim que tem que ser explorada, mas antes de tudo bem conhecida. 


\section{Objetivos}

O presente trabalho tem como objetivo a otimização das condições de renaturação de três toxinas agregadas, apresentando no mínimo 5 pontes dissulfídicas, através da aplicação de altas pressões hidrostáticas, bem como a realização de análises físico-química ou de atividade biológica das proteínas submetidas ao processo de renaturação. 


\section{Material e Métodos}

\subsection{Material}

\subsubsection{Equipamentos}

Aparelho Mili-Q Plus, purificador de água em sistema MIlliQ (18 $\Omega$ ) Milipore, Belford, MA, E.U.A.

Autoclave modelo 415 FANEM, São Paulo, Brasil

Banho Maria FANEM Modelo 100

Banho Maria Type 16500 Dry-Bath, Thermolyne, lowa, E.U.A.

Balança analítica AW 220, Shimadzu, Japão

Balança de precisão P1200, Metter, São Paulo, Brasil

Câmara de Neubauer Tiefe, Loptik Labor, Basel, Suíça

Câmera fotográfica Axion - cam IcC1- Zeiss, E.U.A.

Centrífuga LS3-Plus, CELM, São Paulo, Brasil

Centrífuga 5810R, Eppendorf, Alemanha

Centrífuga Sorvall Speed RC2-B, E.U.A.

Eletro-porador Invitrogen, São Paulo, Brasil.

Estufa para cultura bacteriana Quimis, Diadema, Brasil.

Estufa de CO2 para cultura celular 3158 Farma Scientific, Ohio, E.U.A.

Filmes radiográficos, Kodak Dental, Canadá

Fluxo laminar 2256, Trox, Curitiba, Brasil.

Freezer $-80^{\circ} \mathrm{C}$, AL880 E, American Lab, São Paulo, Brasil.

GradFraq Pharmacia

Incubadora refrigerada com agitação TE 421 Tecnal

Leitor de Elisa Molecular Devices SpectraMax 190, Sunnyvale, EUA.

Leitor DO. Ultrospec 10 Amersham Bioscience, EUA 
Microondas LG, Brasil

Microscópio óptico Axio Imager A1, Carl Zeiss, E.U.A.

Microscópio invertido TMS, Nikon, Japão

Microscópio eletrônico de varredura Phillipis, modelo XL30, Holanda

Prensa Isostática HIP, Pensilvânia, EUA

Seladora a vácuo TecMaq TM 150, São Paulo, Brasil

Sistema de Eletroforese vertical, SE250, Hoefer, Pharmacia Biotech, San

Francisco, EUA.

Sistema de estocagem de criotubos em nitrogênio Líquido, Thermolyne, Dubuque,

IA, EUA.

Sonicador Sonifier Cell Disruptor, Canadá

\subsubsection{Reagentes e soluções}

Acrilamida, BioAgency

Agar, BD

Ampicilina, Bayer

Anestésico Ketamina, doação

Antibióticos e antimicóticos, Gibco, Life Technologies, Grand Island, N.Y., E.U.A.

Bicarbonato de Sodio, Gibco BRL, Gathesburg, M.D., E.U.A.

Bis-acrilamida, BioAgency

$\mathrm{CaCl}$, doação

Casaaminoácidos, BD

Clorafenicol, Sigma, C0378

Comassie Blue G-250

Deoxicolato de sódio, Sigma, D6750

DTT, Sigma, D5545.

EDTA, doação

Extrato de levedura, Acumedia

Fosfato de Sódio, doação

Glicerol, Serva

Glicose, Casa Americana

Glutationas reduzida e oxidada, Sigma, G6529/G4376

Guanidina, Sigma, G4630

Imidazol, USB Corporation 
Isopropil, $\beta$-D-tiogalactopiranosídeo (IPTG), Sigma, 15502

Kanamicina, USB

Kit quimioluminescência para revelação de Western blotting ECL+Plus, Amersham Pharmacia Biotech, Buckinghamshire, UK.

$\mathrm{K} 2 \mathrm{SO} 4$ doação

I-Arginina, Merk

Leite em pó desnatado e liofilizado, Molico, São Paulo, Brasil

Lisozima, Sigma, L6876

L-Glutamina, Sigma.

Meio DMEM, Gibco

MgSO4, doação

$\mathrm{NaCl}, \mathrm{Vetec}$

NiSO4, GEHealthcare

Padrão de peso molecular, Sigma, M3913

PEG 600, doação

Relaxante muscular Xilasina, doação

Sacarose, Ecebra

Solução fixadora Kodak Dental, Canadá

Solução Reveladora Kodak Dental, Canadá

Soroalbumina bovina, Sigma, A3294

Sorofetal bovino, Vitrocell

Surfaína, doação

Triptona, Difco

Tris, Amersham Bioscience

Triton X-100 doação

Tween-20 Aldrich

Uréia, Poliscience

\subsubsection{Linhagem bacteriana}

A linhagem de Escherichia coli BL21(DE3): hsdS Gal ( $\lambda$ clts857 ind1 Sam7 nin5 lac UV5-T7-gene 1) foi usada para expressão das três proteínas. 


\subsubsection{Linhagem de células eucariotas}

A linhagem celular $\mathrm{C} 2 \mathrm{C} 12$ foi produzida por $\mathrm{H}$. Blam e cols. a partir de mioblastos de camundongos. 


\subsection{Métodos}

\subsubsection{Transformação e expressão}

O gene da Naterina 2 foi inserido em um plasmídeo pAE utilizado para a expressão em E. coli BL21 (DE3)StarPlys, (Magalhães). O gene bothropstoxina1 foi inserida em um plasmídeo pet 24a+, e a expressão foi realizada em cepas de E. coli BL21 DE3 (Spencer e cols., 2000). Para a expressão de NXH8 foi utilizado o plasmídeo pRSETC-nxh8M em células de E. coli BL21 (DE3). O codon iniciador é seguido de um fragmento codificante para 10 aminoácidos da proteina do capsideo do gene 10 do fago T7, do fragmento codificante da cauda de 6 resíduos de histidina, da sequencia codificante para o sítio de clivagem pela enteroquinase e do cDNA da parte madura do homólogo da neurotoxina. (Prieto, 2002).

As cepas BL21(DE3) de E. coli foram transformadas por eletroporação e em seguida inoculadas em meio Ágar LB (10 g de triptona/L, $5 \mathrm{~g}$ de extrato de levedura/L, $10 \mathrm{~g}$ de $\mathrm{NaCl} / \mathrm{L}$ e $15 \mathrm{~g}$ ágar/L), contendo o antibiótico adequado (tabela 1). As culturas foram mantidas em estufa por 16 horas a $37^{\circ} \mathrm{C}$. Colônias foram aleatoriamente escolhidas e repicadas em $15 \mathrm{~mL}$ de meio LB e mantidas em incubadora a $37^{\circ} \mathrm{C}$ com agitação de $150 \mathrm{rpm}$. Este volume foi então diluído em $250 \mathrm{~mL}$ de meio de cultura rico $2 \mathrm{HKII}$ (20 g de triptona/L, $10 \mathrm{~g}$ de extrato de leveduras/L, $4 \mathrm{~g}$ de casaminoácidos/L, 0,8 $\mathrm{g}$ de $\mathrm{MgSO}_{4} / \mathrm{L}, 0,08 \mathrm{~g}$ de $\mathrm{CaCl}_{2} / \mathrm{L} \mathrm{3,1} \mathrm{g}$ $\mathrm{K}_{2} \mathrm{SO} 4 / \mathrm{L}$ e $380 \mu \mathrm{L}$ de solução traços de metais/L), em frascos de $1000 \mathrm{~mL}$, contendo antibiótico e mantidas a $200 \mathrm{rpm}$ a $37^{\circ} \mathrm{C}$ até atingirem a D.O. de 3,0 (leitura em espectrofotômetro em comprimento de onda de $600 \mathrm{~nm}$ ). As culturas foram então ativadas pela adição de isopropil- $\beta$-D-tiogalactopiranosideo (IPTG) em concentração final de $0,5 \mathrm{mM}$ e mantidas às mesmas temperatura e rotação por mais 16 horas. 
A amostra para controle negativo de atividade biológica da Naterina 2 consistiu em extratos de bactérias que continham o plasmídeo mas não o gene da Naterina 2, tratadas do mesmo modo que as bactérias expressando esta proteína.

Tabela 1: antibióticos usados

\begin{tabular}{ll}
\hline Proteína & Antibiótico \\
\hline Bothropstoxina 2 & Kanamicina $(50 \mu \mathrm{g} / \mathrm{ml})$ \\
Naterina 2 & Ampicilina $(100 \mu \mathrm{g} / \mathrm{ml})$ e Clorafenicol $(50 \mu \mathrm{g} / \mathrm{ml})$ \\
NXH8 & Ampicilina $(100 \mu \mathrm{g} / \mathrm{ml})$ \\
\hline
\end{tabular}

\subsubsection{Lavagem dos corpos de inclusão}

A suspensão bactérias foi centrifugada a $2.500 \mathrm{~g}$ por $15 \mathrm{~min}$, sendo descartado o sobrenadante. O precipitado insolúvel foi ressuspenso em tampão adequado para cada proteína (tabela 2) contendo lisozima em uma concentração final de $50 \mu \mathrm{g} / \mathrm{mL}$. A suspensão foi incubada em temperatura ambiente por 30 minutos e em seguida foi sonicada por 5 períodos de 30 segundos com intervalos de 30 segundos a $60 \mathrm{~Hz}$ em banho de gelo. A suspensão foi novamente centrifugada a $10.000 \mathrm{~g}$ por $15 \mathrm{~min}$, o sobrenadante foi descartado e o precipitado insolúvel ressuspenso em tampão de lavagem adequado para cada proteína (tabela 2). A suspensão foi sonicada para que houvesse uma homogenização da suspensão de corpos de inclusão e o procedimento de lavagem dos corpos de inclusão foi repetido $5 X$ com todas as proteínas.

Após o término das lavagens, os corpos de inclusão foram ressuspensos em tampão de renaturação, também adequados para cada proteína (tabela 2) e armazenados a $-20^{\circ} \mathrm{C}$. 
Tabela 2: Soluções-tampão utilizadas para renaturação das três proteínas.

\begin{tabular}{|c|c|c|c|c|}
\hline & $\begin{array}{l}\text { Tampão de } \\
\text { Lise }\end{array}$ & Tampão de lavagem & $\begin{array}{l}\text { Tampão de } \\
\text { renaturação }\end{array}$ & $\begin{array}{l}\text { Tampão de } \\
\text { diálise }\end{array}$ \\
\hline NXH8 & $\begin{array}{l}\text { Tris } \mathrm{HCl} 50 \mathrm{mM} \\
\mathrm{pH} 9,0+50 \\
\mu \mathrm{g} / \mathrm{mL} \\
\text { lisozima }\end{array}$ & $\begin{array}{l}\text { Tris HCl } 50 \text { mM } \\
\text { pH 9,0 } \\
+3 \mathrm{M} \text { uréia + 0,1\% } \\
\text { deoxicolato de sódio }\end{array}$ & $\begin{array}{l}\text { Tris HCl } 50 \\
\mathrm{mM}+ \\
1 \mathrm{mM} \text { EDTA }\end{array}$ & $\begin{array}{c}\text { Tris } \mathrm{HCl} \\
50 \mathrm{mM} \\
\mathrm{pH} \mathrm{7,0}\end{array}$ \\
\hline Naterina 2 & $\begin{array}{l}\text { Tris } \mathrm{HCl} 20 \mathrm{mM} \\
\mathrm{pH} 8,0+50 \\
\mu \mathrm{g} / \mathrm{mL} \\
\text { de lisozima }\end{array}$ & $\begin{array}{l}\text { Tris } \mathrm{HCl} 20 \text { mM } \\
\mathrm{pH} 8,0 \\
+3 \mathrm{M} \text { uréia }+0,1 \% \\
\text { deoxicolato de sódio }\end{array}$ & $\begin{array}{l}\text { Tris } \mathrm{HCl} 20 \\
\mathrm{mM}+1 \mathrm{mM} \\
\text { EDTA }\end{array}$ & $\begin{array}{l}\text { Tris HCl } \\
20 \mathrm{mM} \\
\mathrm{pH} 8,0\end{array}$ \\
\hline $\begin{array}{l}\text { Bothrops } \\
\text { toxina } 2\end{array}$ & $\begin{array}{l}\text { Tris } \mathrm{HCl} 50 \mathrm{mM} \\
\mathrm{pH} 7,5 \\
2 \mathrm{mM} \text { EDTA } \\
0,1 \% \\
\text { Triton X-100 + } \\
50 \mu \mathrm{g} / \mathrm{mL} \\
\text { lisozima }\end{array}$ & $\begin{array}{l}\text { Tris HCI } 50 \text { mM } \\
\mathrm{pH} 7,5 \\
\text { 2mM EDTA 0,1\% } \\
\text { Triton X-100 + 3 M } \\
\text { uréia }\end{array}$ & $\begin{array}{l}\text { Tris HCl } 50 \\
\mathrm{mM}+1 \mathrm{mM} \\
\text { EDTA }\end{array}$ & $\begin{array}{l}\text { Tris HCl } \\
50 \mathrm{mM} \\
\mathrm{pH} \mathrm{7,5}\end{array}$ \\
\hline
\end{tabular}

\subsubsection{Renaturação}

Os corpos de inclusão lavados foram diluídos em tampão de renaturação, em diferentes concentrações de agentes desnaturantes, aditivos, concentração de corpos de inclusão e pH como indicado nos próximos tópicos. As densidades ópticas (D.O.s) das suspensões de corpos de inclusão foram determinadas em espectrofotômetro em comprimento de onda de $600 \mathrm{~nm}$. Amostras de $0,5 \mathrm{~mL}$ de suspensão foram colocadas em saquinhos plásticos que foram selados. Os saquinhos foram introduzidos em um único saco plástico maior, o qual foi selado a vácuo. Os sacos plásticos foram então colocados no vaso de pressão e submersos em uma mistura de água e óleo. Altas pressões foram aplicadas (2000 bar) por 16 horas. As amostras foram então retiradas dos sacos plásticos e centrifugadas a $12.000 \mathrm{~g}$ por 15 min para a remoção de agregados insolúveis. Os sobrenadantes foram dializado contra o tampão respectivo (tabela 2) e 
centrifugado novamente para a remoção de agregados insolúveis. Posteriormente as frações solúveis foram analisadas por SDS-PAGE.

\subsubsection{Concentrações de agentes solubilizantes}

O hidrocloreto de guanidina $(\mathrm{GdnHCl})$ foi utilizado como agente solubilizante, em concentrações que variaram entre 0 e $6 \mathrm{M}$.

Os reagentes glutationas oxidada e reduzida foram utilizados como par oxido/redutor. Foi variada tanto a concentração final, entre 0 a $20 \mathrm{mM}$ dos dois reagentes, quanto a proporção de cada um, sendo estas de: 1:9; 1:4; $2: 3 ; 1: 2 ; 1: 1$; $2: 1 ; 3: 2 ; 4: 1 ;$ e, $9: 1$.

\subsubsection{Aditivos, pH e D.Os. dos corpos de inclusão}

Os aditivos testados foram: $\mathrm{NaCL}(0,15 \mathrm{M})$, L-Arg (0,5 M), Triton X-100 (0,5 mM), Glicerol (2,5 M), Glicose (4 M), Sacarose (1 M), PEG 6000 (0,1\%), Surfaína ( $1 \%$ e $0,1 \%)$, e Tween 20 ( $1 \mathrm{mM})$, nos tampões de renaturação adequados para cada uma das três toxinas.

Os pHs do tampão de cada condição de renaturação estão indicados na tabela 3.

Tabela 3: pHs dos tampões de renaturação variando de acordo com o PI de cada proteína

\begin{tabular}{lll}
\hline Proteína & $\mathrm{PI}$ & Variação de $\mathrm{pH}$ no tampão de renaturação \\
Bothropstoxina 1 & 8,2 & 5,5 a 9,0 \\
Naterina 2 & 8,51 & 5,5 a 9,0 \\
NXH8 & 7,8 & 5,5 a 9,0 \\
\hline
\end{tabular}

Foram também utilizadas diferentes D.O. $\left(\mathrm{A}_{600} \mathrm{~nm}\right)$ dos corpos de inclusão em solução de renaturação. As D.O.s testadas foram: 0,$5 ; 1 ; 2 ; 4 ; 6 ; 8 ; 10 ; 12 ; 14$; $16 ; 18 ;$ e, 20.

\subsubsection{Microscopia eletrônica de varredura}

A microscopia eletrônica de varredura (MEV) foi feita para observar se a forma dos corpos de inclusão foi modificada durante o processo de renaturação, o 
que indicaria se eles foram solubilizados durante a pressurização e reagregaram ao voltar à pressão atmosférica. Foram feitas MEV dos corpos de inclusão antes da pressurização, do precipitado após a pressurização e do precipitado formado durante a diálise. Os precipitados foram lavados com água destilada para que fosse retirada todo o Tris da solução tampão, pois este reagente forma cristais que interferem na visualização dos agregados. Após a lavagem das amostras insolúveis de cada passo da renaturação elas foram ressuspensas em 50 a 100 $\mu \mathrm{L}$ de água e foram aplicadas em porta-amostras para análise em microscopia eletrônica. Os porta-amostras foram deixados para secar em dessecador e em seguida foi aplicado banho de ouro. As amostras foram visualisadas e fotografadas em microscópio eletrônico de varredura.

\subsubsection{Dicroísmo circular}

As amostras de NXH8 purificadas por IMAC foram dialisadas em tampão fosfato de sódio $10 \mathrm{mM} \mathrm{pH} \mathrm{9,0.} \mathrm{O} \mathrm{intervalo} \mathrm{de} \mathrm{temperatura} \mathrm{foi} \mathrm{de} 20^{\circ} \mathrm{C}$ a $100{ }^{\circ} \mathrm{C}$ de $10 \mathrm{em} 10^{\circ} \mathrm{C}$. A seguir foi feita mais uma leitura a $20^{\circ} \mathrm{C}$.

O espectro de dicroísmo circular foi obtido usando-se um espectropolarimetro JASCO - J810, com temperatura controlada, usando-se uma cubeta de $0,1 \mathrm{~cm}$. Os dados da curva de elipticidade foram obtidos pela análise da média de cinco medidas.

\subsubsection{Fluorescência}

O espectro de fluorescência foi obtido pelo aparelho F4500 Hytachi, usando-se uma cubeta de $1 \mathrm{~cm}$, com as quatro faces polidas. As amostras foram diluidas em tampão Tris- $\mathrm{HCl} \mathrm{pH} 7,5,50 \mathrm{mM}$ contendo 0 a $6 \mathrm{M}$ de $\mathrm{GdnHCl}$. As análises foram feitas com excitação em $280 \mathrm{~nm}$ e leituras em comprimento de onda de 300 a $400 \mathrm{~nm}$.

\subsubsection{SDS-PAGE, quantificação de proteínas totais e HPLC}

A eletroforese em gel de poliacrilamida (SDS-PAGE) foi realizada com géis de poliacrilamida em concentrações de 15 e 12,5\%, dependendo da amostra analisada. Os géis foram corados com Comassie Blue G-250. 
Concentrações protéicas de amostras foram determinadas pelo método Bradford 1976, usando-se soroalbumina bovina (SBA) pura como padrão. Foram feitas duas curvas de SBA, uma com $8 \mathrm{M}$ de uréia e a outra sem uréia. As amostras insolúveis foram solubilizadas em tampão contendo uréia (8M) e lidas na curva de SBA com uréia. Para as amostras solúveis foi utilizada a curva de SBA sem uréia. As amostras em volume de $25 \mu \mathrm{l}$, foram incubadas com $750 \mu \mathrm{l}$ de reagente de Bradford por 10 minutos e em seguida foram feitas as leituras em 295 $\mathrm{nm}$ em leitor de Elisa.

A cromatografia de exclusão molecular em HPLC foi realizado utilizando-se uma coluna Tosohaas (Montgomeryville, PA, USA) G2000 SW (60 cm X $7.5 \mathrm{~mm}$ diâmetro, partículas de tamanho $10 \mu \mathrm{m}$, poros de $125 \AA$ ) acoplada a uma précoluna SW de $7,5 \mathrm{~cm} \times 7,5 \mathrm{~mm}$ de diâmetro. A fase móvel usada foi tampão fosfato de sódio $20 \mathrm{mM}$, pH 7,0 contendo $50 \mathrm{mM}$ de $\mathrm{NaCl}$. As amostras foram detectadas por absorbância em UV em um comprimento de onda de 220 nm.

\subsubsection{Purificação de NXH8 por cromatografia de afinidade por metais imobilizados.}

Amostras renaturadas de NXH8 foram submetidas à purificação por IMAC em coluna HisTrap (GE Healthcare) de $1 \mathrm{~mL}$ carregada com Níquel (NiSO4), prélavada com tampão TrisHCl $50 \mathrm{mM}, \mathrm{pH} 7,5$ contendo $0,5 \mathrm{M}$ de $\mathrm{NaCl}$. As amostras, no mesmo tampão, foram aplicadas na coluna de purificação. A resina foi lavada com $5 \mathrm{~mL}$ do mesmo tampão contendo $20 \mathrm{mM}$ de imidazol para se retirar ligantes fracos ou proteínas que não se ligaram à matriz. A NXH8 foi eluída no mesmo tampão contendo $300 \mathrm{mM}$ e $500 \mathrm{mM}$ de imidazol e posteriormente dialisadas em Tris $\mathrm{HCl} 50 \mathrm{mM} \mathrm{pH} \mathrm{7,5.} \mathrm{As} \mathrm{amostras} \mathrm{resultantes} \mathrm{foram} \mathrm{submetidas} \mathrm{à} \mathrm{análise} \mathrm{de}$ Bradford para quantificação da proteína e determinação da fração de interesse. A amostra foi concentrada por centrifugação em filtros com poros apropriados (centricon) para um volume de $2 \mathrm{~mL}$.

\subsubsection{Cultura celular}

As células $\mathrm{C}_{2} \mathrm{C}_{12}$ foram acondicionadas em frascos apropriados contendo meio de congelamento que consiste em 10\% de DMSO (Dimetil-Sulfóxido MERCK), 40\% de Soro Fetal Bovino (FCS; Sigma F-2442) e 50\% de meio RPMI (1640 Medium - Sigma) em nitrogênio líquido. Uma ampola foi retirada do 
nitrogênio líquido e colocada em banho- maria a $37^{\circ} \mathrm{C}$ por 3 minutos. As células foram diluídas em $10 \mathrm{ml}$ de meio DMEM e centrifugadas por 5 minutos a 1500 rpm. O sobrenadante foi descartado e as células foram ressuspensas e colocadas um uma garrafa apropriada para cultura de células aderentes, de $25 \mathrm{~cm}^{2}$, onde foram cultivadas em meio DMEM suplementado com 10\% de SFB (soro fetal bovino) $1 \%$ de L-Glutamina, 1\% de Gentamicina-Streptomicina, $2 \mathrm{~g}$ de bicarbonato de sódio, em uma atmosfera umedecida em $5 \%$ de $\mathrm{CO} 2$ a $37^{\circ} \mathrm{C}$.

Após chegarem à semi-confluência, as células foram submetidas à tripsinização para descolamento. Foram adicionados $1,5 \mathrm{ml}$ de Tripsina 0,5 \% e a garrafa foi incubada por 3 minutos na estufa. Adicionou-se $5 \mathrm{ml}$ de meio DMEM contendo $10 \%$ de SFB na garrafa a fim de inativar a ação da Tripsina. O conteúdo foi transferido para um tubo de centrífuga de $15 \mathrm{ml}$ e centrifugado por 5 minutos à 1500 rpm. O precipitado foi ressuspendido em $10 \mathrm{ml}$ de PBS (tampão fosfato salina) e as células foram contadas em câmara de Neubauer. As células foram novamente centrifugadas, ressuspendidas em meio DMEM e semeadas em microplacas de 96 poços em uma densidade inicial de 1 a $4 \times 10^{4}$ células por poço em $150 \mu \mathrm{l}$ do mesmo meio. Quando as células atingiram a semi-confluência, após 3 a 5 dias, o meio foi substituído por meio de diferenciação, o qual é constituído de DMEM suplementado com 1\% de Soro Fetal Bovino (Lomonte, 1999). Depois de 4-6 dias de cultura, uma vasta proporção de miotúbulos multinucleados foi observada, sendo estas células então utilizadas nos ensaios de citotoxicidade. Para fins de comparação, células não diferenciadas também foram utilizadas para o ensaio.

\subsubsection{Determinação de Desidrogenase láctica (LDH)}

A fim de verificarmos a ação citotóxica da Bothropstoxina 1 a $3 \times 10^{4}$ de células musculares murinas $\left(\mathrm{C}_{2} \mathrm{C}_{12}\right)$, diferenciadas em miotúbulos e a mesma quantidade de células indiferenciadas (mioblastos) foram utilizadas. Concentrações de Bothropstoxina 1, variando entre 0 e $40 \mathrm{mg}$ foram aplicados em em $150 \mu \mathrm{L}$ e em duplicatas aos poços da placa de 96 poços. Para o controle de lise celular (controle positivo) foi adicionado $0,1 \%$ de Triton $\mathrm{X}-100$. A placa foi incubada por 3 horas e a seguir foi centrifugada. $O$ sobrenadante foi transferido para outra placa para a realização do teste utilizando o kit LDH Liquiform da 
Labtest de determinação de LDH, que é liberada das células sob a ação da toxina. Foi adicionado $250 \mu \mathrm{L}$ do substrato (uma proporção de 1:4 dos reagentes $A$ e B) mais $5 \mu \mathrm{L}$ do sobrenadante celular, segundo protocolo do fabricante. As leituras foram feitas em leitor de Elisa a $340 \mathrm{~nm}$ nos tempos $0,1,2$ e 3 minutos.

\subsubsection{Microscopia intravital}

\section{Alterações na microcirculação e em fibras musculares}

Os procedimentos empregados para realização deste ensaio foram descritos por Baez (1973) e Lomonte e colaboradores (1994). Para a avaliação dos efeitos da naterina 2 na microcirculação, camundongos $(n=3)$ foram injetados com Xilasina 0,4\% e posteriormente anestesiados com Ketamina 0.03\%. Em seguida os animais sofreram manipulação cirúrgica na bolsa escrotal para exposição do músculo cremaster e foram colocados sobre uma placa dotada de área transparente, sobre a qual o tecido foi fixado. A placa foi montada sobre o "charriot" do microscópio óptico e $20 \mu \mathrm{L}$ de controle da cultura de BL21 ou da amostra foram aplicados topicamente sobre o cremaster. As alterações foram observadas por um período de 30 minutos e registradas a cada 5 minutos. Foram avaliadas alterações induzidas pelas amostras nos vasos (arteríolas e vênulas), rolamento e adesão de leucócitos, formação de trombos e alterações em fibras musculares.

\subsubsection{Western Blotting}

A fim de verificarmos a presença de pontes dissulfídicas na NXH8, foi realizada a análise por western blotting. Uma eletroforese em gel de poliacrilamida (SDS-PAGE) $15 \%$ foi realizada com $40 \mu \mathrm{L}$ de amostra sendo aplicada uma amostra reduzida e outra não reduzida com 100 mM de DTT. Ao final da corrida do gel, foi feita a transferência por eletroiluição, para uma membrana de nitrocelulose, pré umedecida com tampão de transferência $(0,3 \%$ glicina, 0,6 \% Tris-base, 0,04\% SDS, $20 \%$ metanol), a corrente foi fixada de acordo com a área de gel $(0,85 \mathrm{~mA}$ por $\mathrm{cm} 2)$ para a transferência total das proteínas por 1 hora. A membrana foi então bloqueada com TBS (Tris $\mathrm{HCl}$ pH 7,5 
$10 \mathrm{mM}+0,9 \% \mathrm{NaCl})+5 \%$ de leite em pó desnatado e liofilizado molico por 30 minutos e depois lavada com TBS por 5 ciclos de 10 minutos cada sob agitação. Foi então incubada com anticorpo primário anti NXH8 numa diluição 1:200 em TTBS (TBS + 0,1\% Tween 20) + $5 \%$ de leite, over night e sob agitação. No dia seguinte, a membrana foi lavada com cinco ciclos de 10 minutos com T-TBS e incubada com anticorpo secundário anti mouse ligados a peroxidase, por 1 hora e 30 minutos. Após este período a membrana foi lavada novamente com T-TBS a reação com a peroxidade foi feita com um Kit quimioluminescência para revelação de Western blotting (ECL+Plus).

\subsubsection{Tabela de conversão de pressão.}

\begin{tabular}{llllllll}
\hline Pressão & \multicolumn{7}{c}{} \\
\hline & $\mathbf{P a}$ & $\mathbf{k P a}$ & $\mathbf{p s i}$ & $\mathbf{k g} / \mathbf{c m}^{2}$ & $\mathbf{b a r}$ & $\mathbf{a t m}$ & $\mathbf{M P a}$ \\
\hline $\mathrm{Pa}$ & 1 & 0.001 & $1.450 \times 10^{-5}$ & $1.020 \times 10^{-5}$ & $1 \times 10^{-5}$ & $9.869 \times 10^{-5}$ & $1 \times 10^{-}$ \\
$\mathrm{kPa}$ & 1000 & 1 & 0.145 & 0.01 & 0.01 & 0.01 & 0.001 \\
$\mathrm{psi}$ & $6.895 \times 10^{3}$ & 6.895 & 1 & 0.07 & 0.069 & 0.068 & 0.007 \\
$\mathrm{~kg} / \mathrm{cm}^{2}$ & $9.807 \times 10^{4}$ & 98.07 & 14.22 & 1 & 0.981 & 0.968 & 0.098 \\
$\mathrm{bar}$ & $1 \times 10^{5}$ & 100 & 14.50 & 1.02 & 1 & 0.987 & 0.1 \\
$\mathrm{~atm}$ & $101.3 \times 10^{5}$ & 101.3 & 14.7 & 1.033 & 1.013 & 1 & 0.101 \\
$\mathrm{MPa}$ & $1 \times 10^{6}$ & 1000 & 145 & 10.2 & 10 & 9.869 & 1 \\
\hline
\end{tabular}




\section{Resultados}

\section{$6.1 \mathrm{NXH8}$}

\subsubsection{Determinação das condições de pressurização}

As Figuras 1 a 6 mostram géis de eletroforese de poliacrilamida de sobrenadantes de suspensão de NXH8 pressurizadas em 2000 bar por 16 horas em diversas condições de tampão de renaturação. Após a pressurização as amostras foram centrifugadas e a seguir dializadas para retirada do $\mathrm{GdnHCl}$. As figuras 1 e 2 mostram a eletroforese em gel de poliacrilamida (SDS-PAGE) dos sobrenadantes das amostras pressurizadas em tampão de renaturação contendo diferentes concentrações e proporções de glutationas oxidada e reduzida. Podemos observar que foi obtido melhor rendimento de NXH8 solúvel quando o par redox na proporção de 1 GSH: 4 GSSG (Figura 1, coluna 3) na concentração final de $6 \mathrm{mM}$ de (Figura 2, coluna 8) foi utilizado no tampão de renaturação.

A Figura 3 mostra que a concentração de $\mathrm{GdnHCl}$ na qual se obteve maior concentração de NXH8 solúvel foi a de $2 \mathrm{M}$ (coluna 8 ). $\mathrm{O} \mathrm{pH}$ escolhido para a renaturação da NXH9 foi de 9,0 (coluna 3 da Figura 4). A figura 5 demonstra que a presença dos aditivos não levou à obtenção de melhores rendimentos de NXH8 solúvel. A figura 6 mostra que os rendimentos de NXH8 solúveis foram proporcionais à diluição das amostras e que portanto, a condição de menor concentração estudada (D.O. $=0,5)$ foi a escolhida (Figura 6, coluna 3). O rendimento de renaturação de NXH8, analisado pelo Bradford, em conjunto com o SDS-PAGE foi de $40 \%$ (dados não mostrados). 


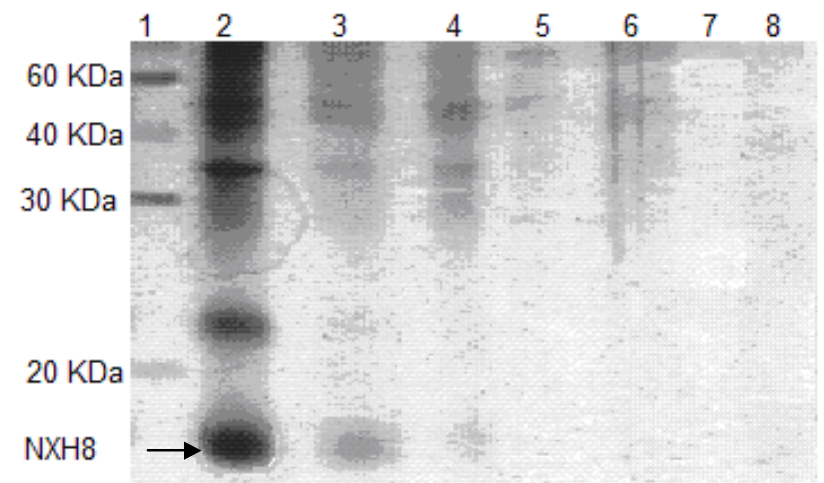

Figura 1: Efeito de diferentes proporções de glutationas reduzida (GSH): oxidada (GSSG) na solubilização da proteína NXH8.Análise por SDS-PAGE não reduzido da NXH8 solúvel obtida em tampão de renaturação contendo $1 \mathrm{M}$ de GdnHCl $10 \mathrm{mM}$ de GSH:GSSG. Coluna 1, Marcador de peso molecular; Coluna 2, corpos de inclusão de NXH8 (amostra insolúvel); Coluna 3, $1 \mathrm{GSH}: 4$ GSSG; Coluna 4, 1 GSH: 2 GSSG; Coluna 5, 1 GSH: 1GSSG; Coluna 6, 2 GSH: 1 GSSG; Coluna 7, 4 GSH:1 GSSG; Coluna 8, Ausência de glutationas.

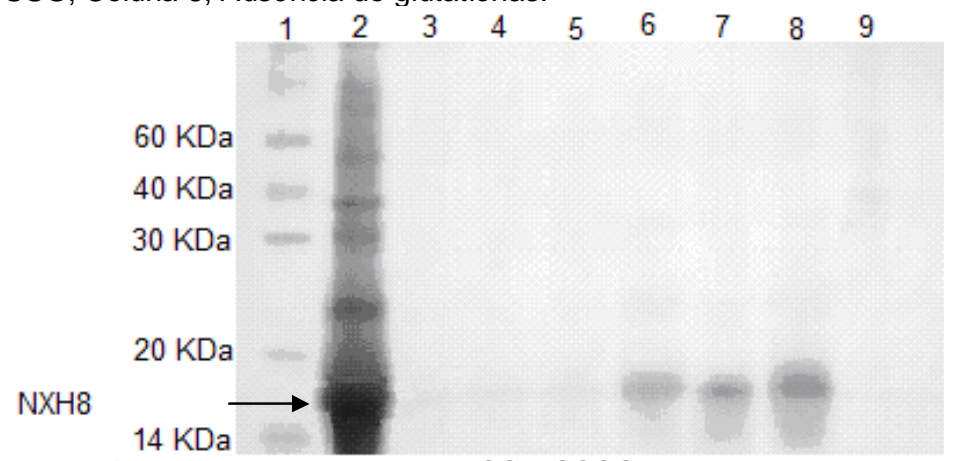

Figura 2: Efeito de diferentes concentrações de GSH:GSSG em proporção 1:4 na solubilização da proteína NXH8. Análise por SDS-PAGE não reduzido da NXH8 solúvel obtida em tampão de renaturação contendo $1 \mathrm{M}$ de GdnHCl. Coluna 1, Marcador de peso molecular; Coluna 2, Corpos de inclusão de NXH8 (amostra insolúvel); Coluna 3, 0 mM de GSH/GSSG; Coluna 4, 0,5 mM de GSH/GSSG; Coluna 5, 1 mM de GSH/GSSG; Coluna 6, 2 mM de GSH/GSSG; Coluna 7, 4mM de GSH/GSSG; Coluna 8, 6 mM de GSH/GSSG; Coluna 9, 10 mM de GSH/GSSG.

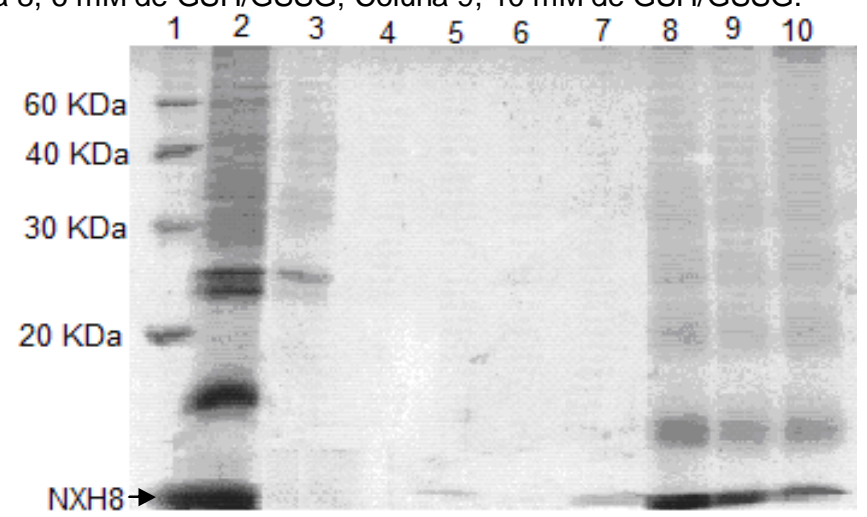

Figura 3: Efeito de diferentes concentrações de $\mathrm{GdnHCl}$ na solubilização da proteína NXH8. Análise por SDS-PAGE não reduzido da NXH8 solúvel obtida em tampão de renaturação contendo $6 \mathrm{mM}$ na proporção de $1 \mathrm{GSH}: 4$ GSSG. Coluna 1, Marcador de peso molecular; Coluna 2, Corpos de inclusão (amostra insolúvel); Coluna 3, $0 \mathrm{M} \mathrm{GdnHCl}$; Coluna 4, 0,25 M GdnHCl; Coluna 5, 0,5 M GdnHCl; Coluna 6, 0,75 M GdnHCl; Coluna 7, $1 \mathrm{M} \mathrm{GdnHCl;} \mathrm{Coluna} \mathrm{8,} 2 \mathrm{M} \mathrm{GdnHCl;}$ Coluna 9, $4 \mathrm{M}$ $\mathrm{GdnHCl}$; Coluna 10, 6M GdnHCl. 


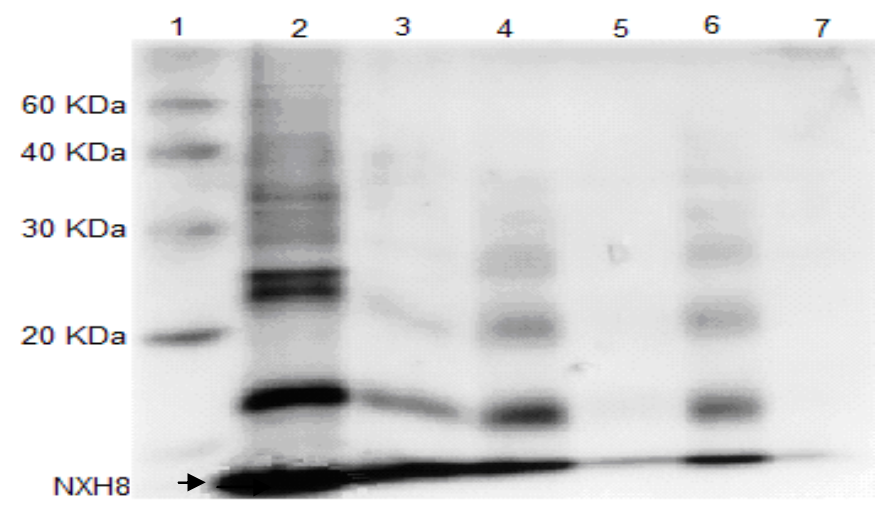

Figura 4: Efeito de pHs na solubilização da proteína NXH8. Análise por SDS-PAGE não reduzido da NXH8 solúvel obtida em tampão de renaturação contendo $6 \mathrm{mM}$ na proporção de $1 \mathrm{GSH}: 4$ GSSG e $2 \mathrm{M} \mathrm{GdnHCl}$. As amostras foram dializadas em tampão pH 7,0. Coluna 1, marcador de peso molecular; coluna 2, corpos de inclusão (amostra insolúvel); coluna 3; Tris $\mathrm{HCl} \mathrm{pH}$ 9,0; coluna 4, Tris $\mathrm{HCl} \mathrm{pH} \mathrm{8,5;} \mathrm{Coluna} \mathrm{5,} \mathrm{Tris} \mathrm{HCl} \mathrm{pH} \mathrm{7,5;} \mathrm{Coluna} \mathrm{6,} \mathrm{Tris} \mathrm{HCl} p H$ 6,5; Coluna 7, Tris $\mathrm{HCl} p H ~ 5,5$.

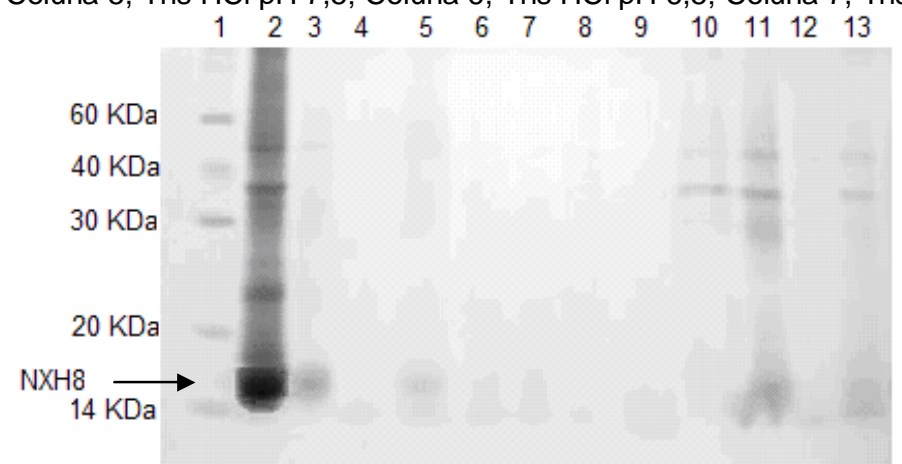

Figura 5: Efeito da presença de aditivos na solubilização da proteína NXH8. Análise por SDSPAGE não reduzido da NXH8 solúvel obtida em tampão de renaturação contendo $6 \mathrm{mM}$ na proporção de 1 GSH:4 GSSG e 2 M GdnHCl pH 9,0. Coluna 1, Marcador de peso molecular; Coluna 2, Corpos de inclusão; Coluna 3, Ausência de aditivos; Coluna 4, $\mathrm{NaCl} \mathrm{0,15} \mathrm{M;} \mathrm{Coluna} \mathrm{5,}$ L-Arg 0,5 M; Coluna 6, PEG 6000 0,1 \%; Coluna 7, Glicose 1M; Coluna 8, Glicerol 2,5 M; Coluna 9, Sacarose 1 M; Coluna 10, Surfaína 1\%; Coluna 11, Surfaína 0,1\%; Coluna 12, Tween 20 0,1 $\mathrm{mM}$; Coluna 13, Triton X-100 0,5 mM.

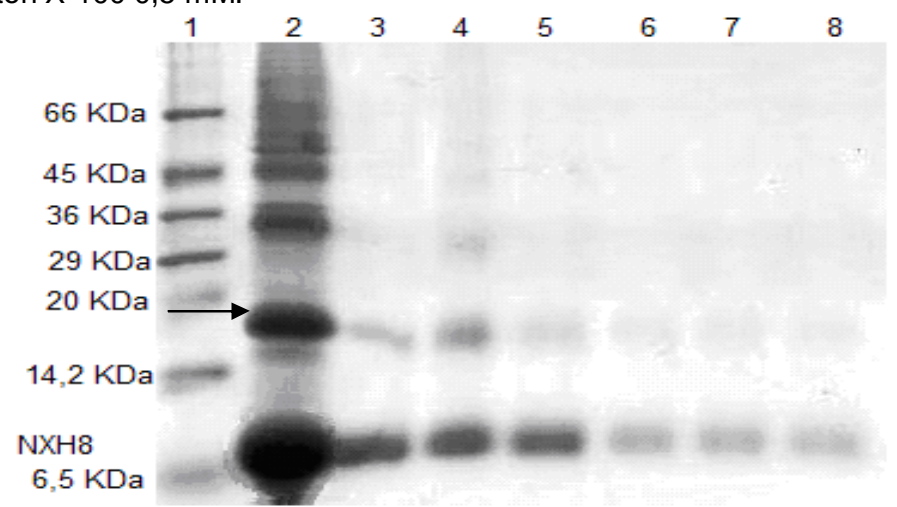

Figura 6: Efeito de diferentes concentrações proteicas no rendimento de renaturação de NXH8. Análise por SDS-PAGE não reduzido de NXH8 solúvel obtida em tampão de renaturação contendo $6 \mathrm{mM}$ na proporção de $1 \mathrm{GSH}: 4 \mathrm{GSSG}$ e $2 \mathrm{M} \mathrm{GdnHCl} \mathrm{pH} \mathrm{7,0.} \mathrm{Coluna1)} \mathrm{Marker;} \mathrm{Coluna} \mathrm{2)} \mathrm{Corpos}$ de inclusão na concentração de 0,5 de D.O.; Coluna 3) 0,5 de D.O.; Coluna 4) 1,0 de D.O.; Coluna5) 2,0 de D.O.; Coluna 6) 4,0 de D.O.; Coluna 7) 6,0 de D.O.; e, Coluna 8) 8,0 de D.O 
A Figura 7 mostra fotografias em microscopia eletrônica de varredura dos corpos de inclusão (Figura 7A), da fração insolúvel dos corpos de inclusão de NXH8 pressurizados (Figura 7B) e também dos agregados formados após diálise da fração solúvel (Figura 7C). Nesta figura pode-se observar que os agregados formados após a pressurização possuem morfologia muito diferente daquela dos corpos de inclusão, indicando que houve a solubilização desses agregados durante a pressurização e que provavelmente ocorreu a reagregação no retorno à pressão atmosférica.
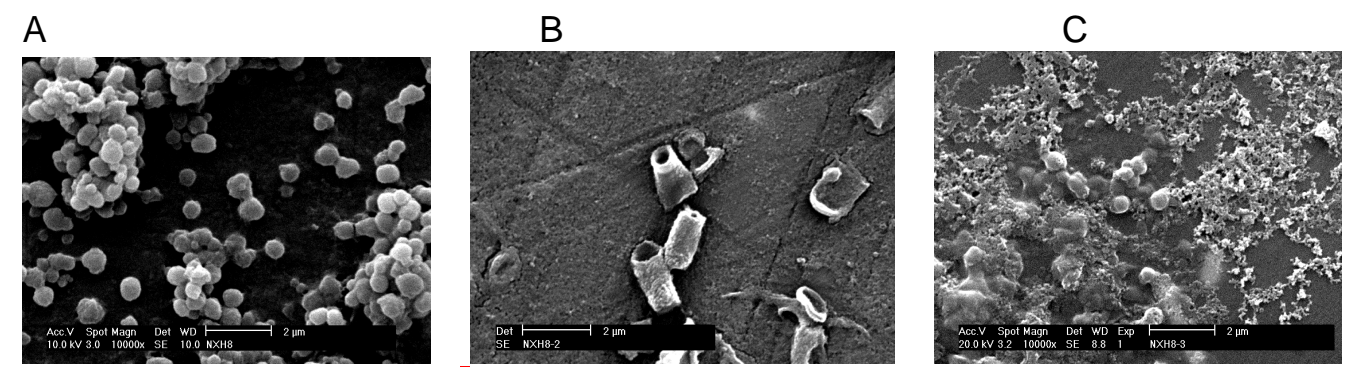

Figura 7: Microscopia eletrônica de varredura (MEV) das diferentes fases do processo de renaturação. A, corpos de inclusão antes da pressurização; $B$, corpos de inclusão após a pressurização; C, agregados formados após a diálise.

\subsubsection{Condição final}

A Figura 8 mostra um gel de eletroforese de todas as fases da obtenção de NXH8 solúvel. Conforme se pode observar na coluna 8 desta figura, a amostra mantida em pressão atmosférica não foi renaturada. $O$ rendimento de renaturação da NXH8 foi de $40 \%$ de NXH8 solúvel a partir de proteína agregada nos corpos de inclusão, tendo sido obtidos 28,6 mg de NXH8 solúvel/L de cultura bacteriana.

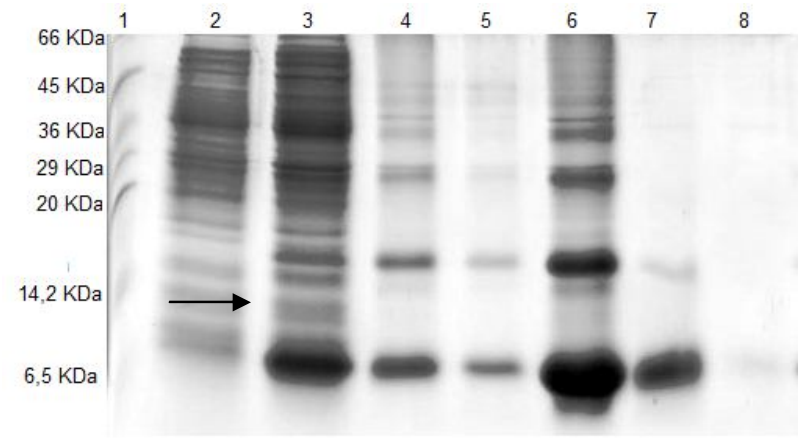

Figura 8: Gel de eletroforese com todas as fases da renaturação. Análise por SDS-PAGE não reduzido de NXH8 solúvel obtida em tampão de renaturação contendo $6 \mathrm{mM}$ de GSH e GSSG na proporção de 1 GSH:4 GSSG, 2 M GdnHCl, renaturação em pH 9,0 e diálise em pH 7,0 e corpos de inclusão na D.O. 0,5, com um rendimento de $40 \%$. Coluna 1, marcador de peso molecular; Coluna 2, bactéria total antes da ativação com IPTG; Coluna 3, bactéria total após a ativação com IPTG; Coluna 4, amostra insolúvel após pressurização; Coluna 5, amostra insolúvel formada após 
diálise; Coluna 6, Corpos de inclusão antes da pressurização; Coluna 7, amostra pressurizada e dialisada; Coluna 8, amostra mantida em pressão atmosférica após diálise.

A purificação por IMAC se mostrou eficiente para o isolamento de NXH8 dos contaminantes, conforme se pode observar na Figura 9. As bandas de peso molecular maior do que $14 \mathrm{KDa}$ que podemos observar na coluna 2 da Figura 9, correspondem às massas moleculares esperadas para dímeros e trímeros desta proteína. A proteína NXH8 se mostrou estável durante etapas de congelamento, descongelamento e purificação, não mostrando sinais de agregação.

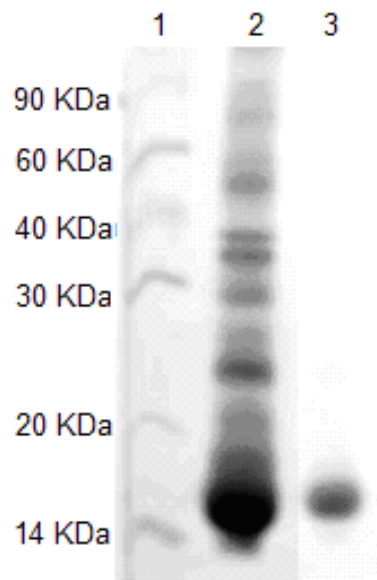

Figura 9: gel de Eletroforese das amostras purificadas por IMAC. Coluna 1, marcador de peso molecular; Coluna 2, corpos de inclusão; Coluna 3, amostra purificada, eluida com $300 \mathrm{mM}$ de imidazol.

Pela análise da NXH8, purificada por IMAC, em coluna de exclusão molecular em HPLC (Figura 9) pode-se verificar um único pico em um tempo de retenção esperado (19,64 minutos) para a massa molecular da NXH8. Como controle foi feita no mesmo dia uma corrida de uma proteína (hormônio de crescimento humano) globular com um peso molecular um pouco maior (de 22 KDa) do que a NXH8 e que apresentou um tempo de retenção de 17,6 minutos, corroborando a suposição de que o pico de 19,6 minutos corresponde à forma monomérica de NXH8. 


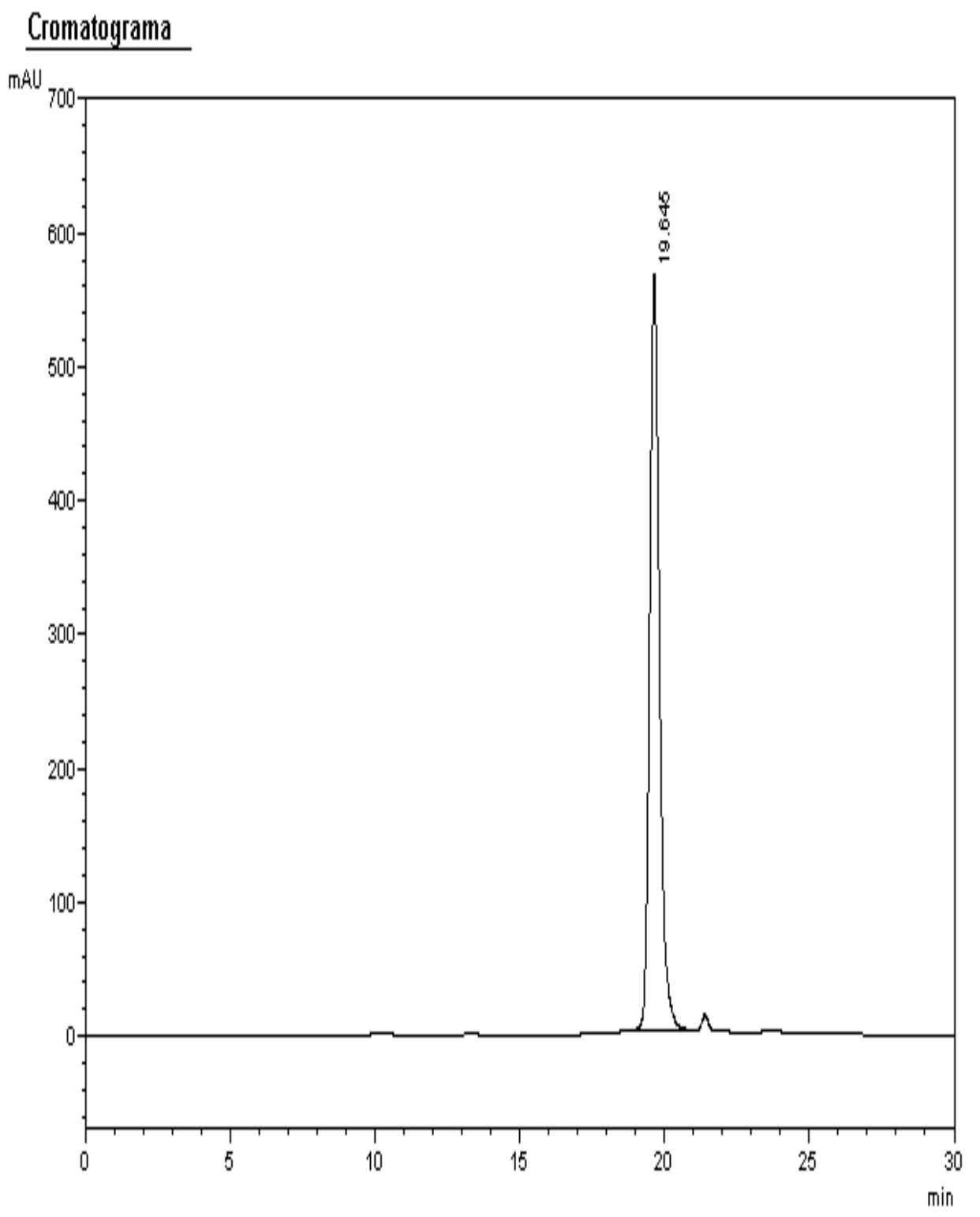

Figura 9: Análise de NXH8 purificada por IMAC, mostrando o tempo de retenção de 19,4 minutos, que corresponde com o esperado para o peso molecular da NXH8. 
As análises por espectroscopia de dicroísmo circular da NXH8 (Figura 10) em diferentes temperaturas mostraram um perfil de proteína desestruturada. Houve uma mudança no perfil com o aumento de temperatura pode ser uma indicação de que NXH8 possui alguma conformação estrutural.

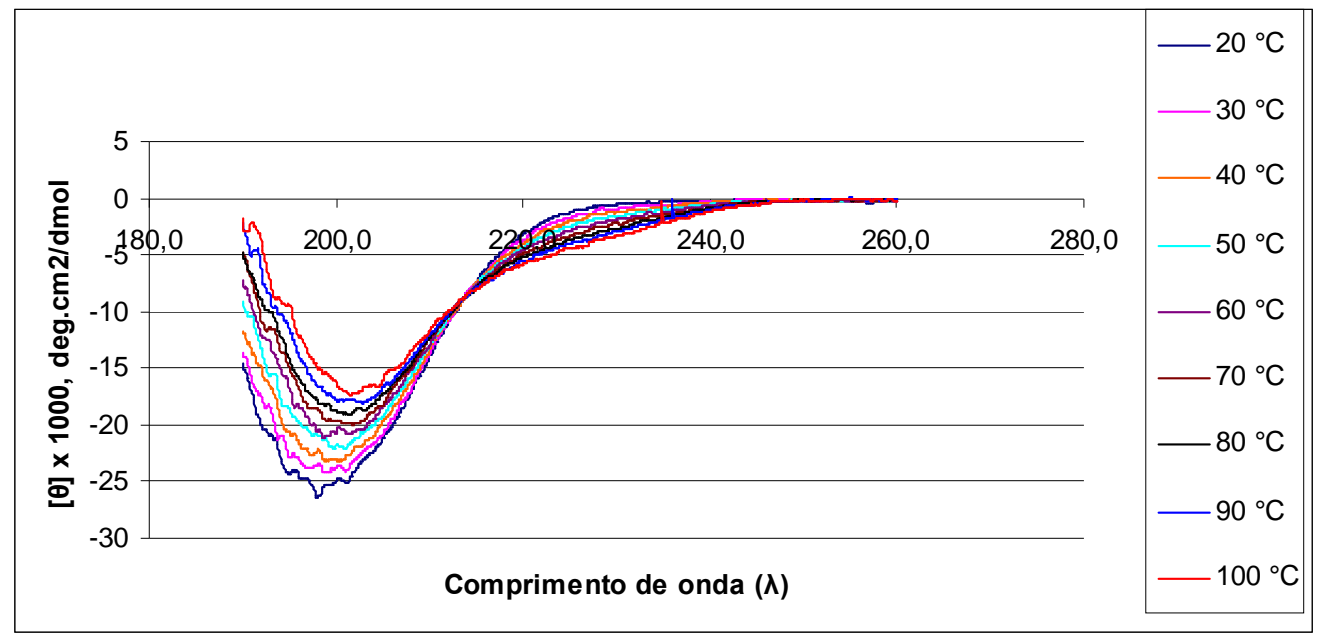

Figura 10: Dicroísmo circular com aumento de temperatura.

A NXH8 possui 1 resíduo de Triptofano. As análises de fluorescência intrínseca do triptofano da NXH8 (figura 11 e Tabela 4), realizadas com excitação em $280 \mathrm{~nm}$ mostram um leve deslocamento para o vermelho (comprimento de onda maior) com o aumento da concentração de uréia, o que indica uma maior exposição dos triptofanos, indicando que houve perda de estrutura com a elevação da concentração do agente desnaturante. 


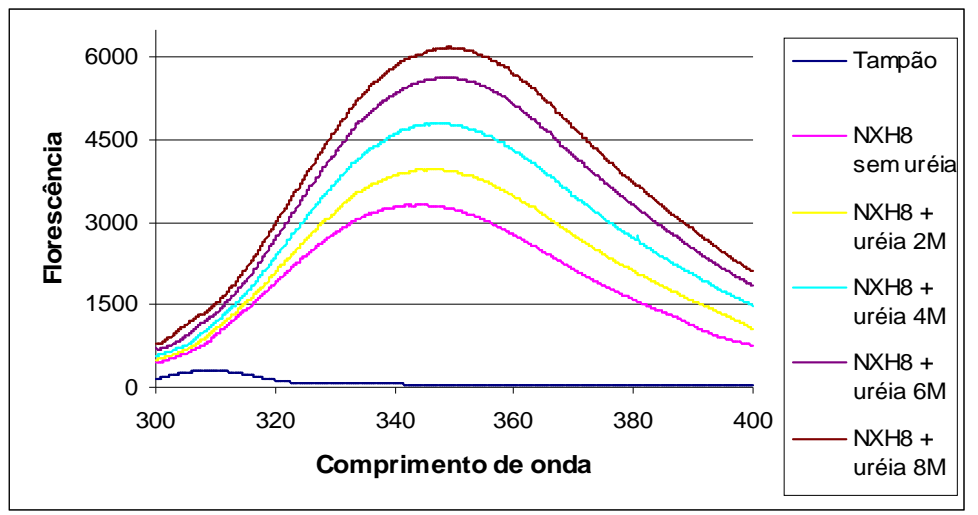

Figura 11: Florescência intrínseca da NXH8 incubada com diferentes concentrações de uréia. Excitação em $280 \mathrm{~nm}$.

Tabela 4: Condições de análise de fluorescência intrínseca de NXH8

\begin{tabular}{ll}
\hline Tampão & Pico máximo de fluorescência (Comprimento de onda $(\mathrm{nm})$ \\
\hline Sem uréia & $344,8 \mathrm{~nm}$ \\
2M uréia & $347,2 \mathrm{~nm}$ \\
$4 \mathrm{M}$ uréia & $348,8 \mathrm{~nm}$ \\
$6 \mathrm{M}$ uréia & $349 \mathrm{~nm}$ \\
$8 \mathrm{M}$ uréia & $349,4 \mathrm{~nm}$ \\
\hline
\end{tabular}

Para verificar se havia a formação de pontes dissulfídicas formadas na NXH8, foi realizado um western blot de amostras reduzidas e não reduzidas. Pela análise (Figura 12), podemos verificar que houve deslocamento da banda de NXH8 na amostra reduzida em comparação com a amostra não reduzida, indicando a presença de pontes dissulfeto na proteína renaturada sob pressão. A banda de menor peso molecular da coluna 2 pode ser um produto de degradação da NXH8. As bandas observadas na coluna 1, acima da correspondente à NXH8, provavelmente são seus respectivos dímeros e trímeros. 


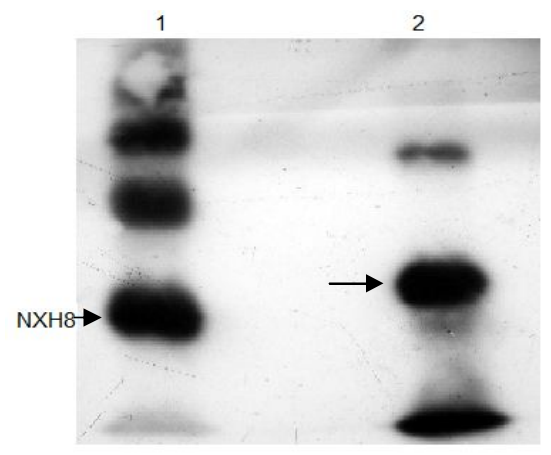

Figura 12: Análise por Western blot da NXH8. O anticorpo utilizado foi o anti-NXH8 produzido em camundongos. O segundo anticorpo foi o anti-lgG de camundongo produzido em coelho. Coluna 1, NXH8 solúvel não reduzida; coluna 2, NXH8 solúvel reduzida.

\subsection{Naterina 2}

\subsubsection{Determinação das condições de pressurização}

As Figuras 13 a 19 mostram géis de eletroforese de poliacrilamida de amostras de Naterina 2 pressurizadas em 2000 bar por 16 horas em diversas condições de tampão de renaturação. Após a pressurização as amostras foram centrifugadas e a seguir dialisadas para retirada do $\mathrm{GdnHCl}$. Nas figuras 13 e 14 podemos observar que foi obtido melhor rendimento de Naterina 2 solúvel quando foi utilizado o par redox no tampão de renaturação na proporção de 2 GSH: 3 GSSG (Figura 13, coluna 6) na concentração total de $10 \mathrm{mM}$ de (Figura 14 , coluna 9).

A Figura 15 mostra que a concentração de $\mathrm{GdnHCl}$ na qual se obteve maior concentração de Naterina 2 solúvel foi a de $1 \mathrm{M}$ (coluna 6). A figura 16 demonstra que a presença do aditivo PEG levou à obtenção de melhores rendimentos de Naterina 2 solúvel (coluna 7). Embora a presença do detergente surfaína também tenha favorecido a solubilização da Naterina 2 (coluna 8), optamos por não utilizar este reagente devido ao fato de ser relatada na literatura a dificuldade de retirada deste tipo de reagente (Clark, 1998). O pH de renaturação escolhido foi o de 9,0 (coluna 9 da Figura 17). A figura 18 mostra que os rendimentos de Naterina 2 solúveis com relação à concentração da suspensão de corpos de inclusão, não interferiu significativamente no rendimento da renaturação, no intervalo de D.O. testado.

O rendimento final da renaturação de Naterina 2 foi de $20 \%$. 


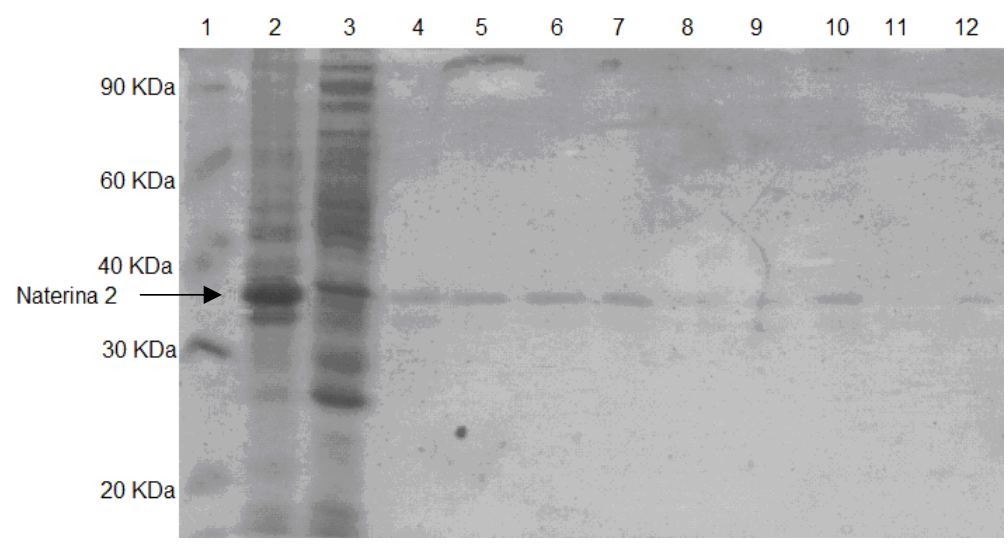

Figura 13: Efeito de diferentes proporções de glutationas oxidada: reduzida na solubilização da proteína Naterina 2. Análise por SDS-PAGE não reduzido da Naterina 2 solúvel obtida em tampão de renaturação contendo $2 \mathrm{M}$ de $\mathrm{GdnHCl}$ e concentração de glutationas oxidada e reduzida de 10 $\mathrm{mM}$ e pH 8. Coluna 1, Marcador de peso molecular; Coluna 2, Corpos de inclusão (amostra insolúvel); Coluna 3, Cultura bacteriana total,a antes da ativação com IPTG; Coluna 4, GSH 1:9 GSSG; Coluna 5, GSH 1:4 GSSG; Coluna 6, GSH 2:3 GSSG; Coluna 7, GSH 1:2 GSSG; Coluna 8, GSH 1:1 GSSG; Coluna 9, GSH 2:1 GSSG; Coluna 10, GSH 3:2 GSSG; Coluna 11, GSH4:1 GSSG; Coluna 12, GSH 9:1 GSSG

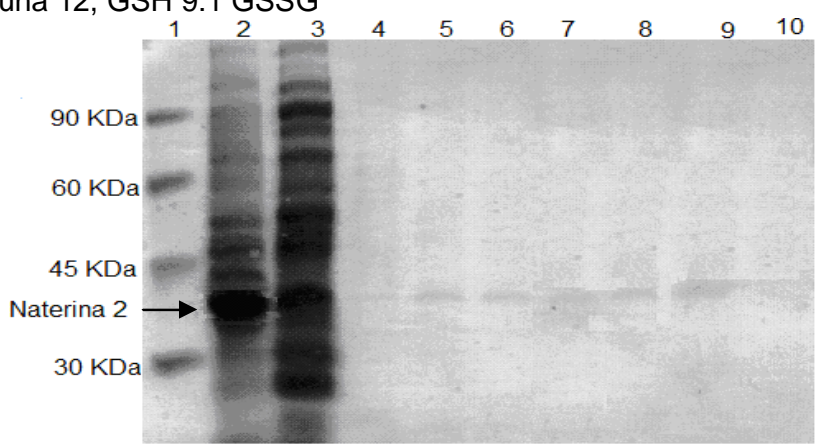

Figura 14: Efeito de diferentes concentrações finais de glutationas oxidada: reduzida em proporção 2:3 na solubilização da proteína Naterina 2. Análise por SDS-PAGE não reduzido da Naterina 2 solúvel obtida em tampão de renaturação contendo $2 \mathrm{M}$ de $\mathrm{GdnHCl}$ e $\mathrm{pH}$ 8. Coluna 1, Marcador de peso molecular; Coluna 2, Corpos de inclusão (amostra insolúvel); Coluna 3, cultura bacteriana total, antes da ativação com IPTG; Coluna 4, 0 mM de GSH/GSSG; Coluna 5, 0,7 mM de GSH/GSSG; Coluna 6, 1,5 mM de GSH/GSSG; Coluna 7, 3 mM de GSH/GSSG; Coluna 8, 6 mM de GSH/GSSG; Coluna 9, 10 mM de GSH/GSSG; Coluna 10, 20 mM de GSH/GSSG.

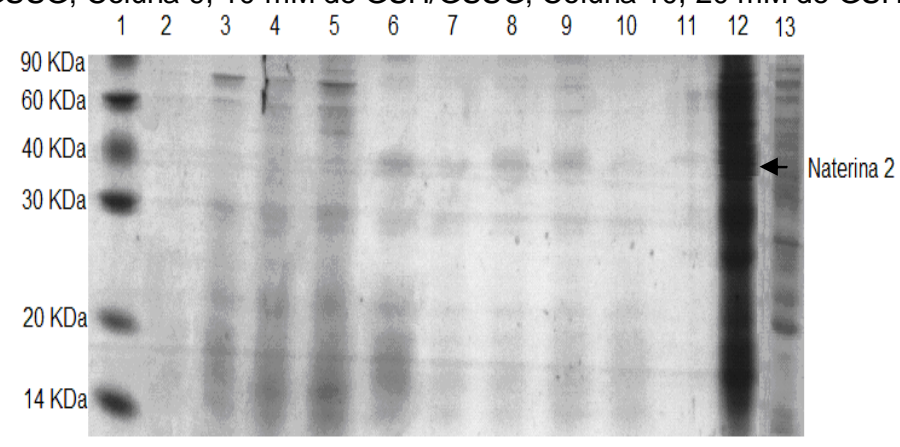

Figura 15: Efeito de diferentes concentrações finais $\mathrm{GdnHCl}$ na solubilização da proteína Naterina 2. Análise por SDS-PAGE não reduzido da Naterina 2 solúvel obtida em tampão de renaturação contendo $10 \mathrm{mM}$ na proporção de 2 GSH:3 GSSG e pH 8. Coluna 1 Marcador de peso molecular; coluna 2, $0 \mathrm{M} \mathrm{GdnHCl}$; coluna 3, 0,25 M GdnHCl; coluna 4, 0,5 M GdnHCl; coluna 5, 0,75 M 
GdnHCl; coluna 6, $1 \mathrm{M} \mathrm{GdnHCl}$; coluna 7, $2 \mathrm{M} \mathrm{GdnHCl}$; coluna 8, 3M GdnHCl; coluna 9, $4 \mathrm{M}$ GdnHCl; coluna 10, $5 \mathrm{M} \mathrm{GdnHCl}$; coluna11, 6M GdnHCl; coluna 12, Corpos de inclusão (amostra insolúvel); Coluna 14, cultura bacteriana total, antes da ativação com IPTG

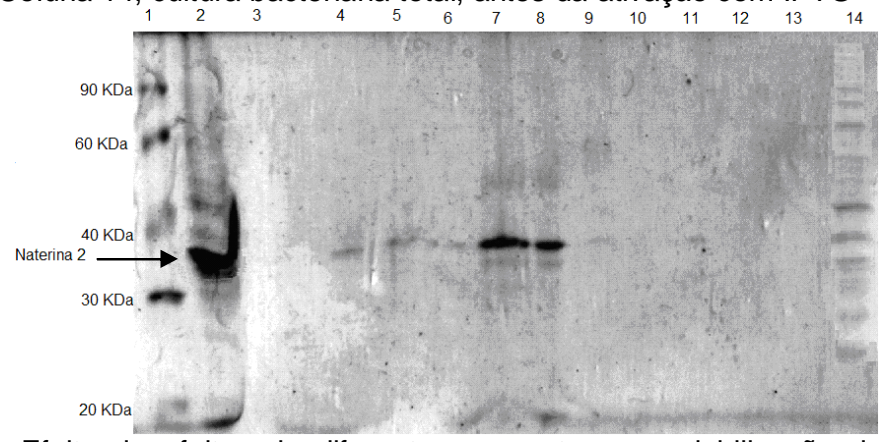

Figura 16: Efeito de efeitos de diferentes reagentes na solubilização da proteína Naterina 2. Análise por SDS-PAGE não reduzido da amostra solúvel obtida em tampão de renaturação contendo $10 \mathrm{mM}$ na proporção de $2 \mathrm{GSH}: 3$ GSSG pH 8,0 e $1 \mathrm{M} \mathrm{GdnHCl}$. Coluna 1, Marcador de peso molecular; Coluna 2, Corpos de inclusão (amostra insolúvel); Coluna 3, Triton X-100 0,5 mM, Coluna 4, $\mathrm{NaCl}$ 0,15 M; Coluna 5, Sem aditivos; Coluna 6, Tween 20 0,1 mM; Coluna 7, PEG 6000 0,1\%; Coluna 8, Surfaína 1\%; Coluna 9, Surfaína 0,1\%; Coluna 10, Glicose 1M; Coluna 11, LArginina 0,5 M; Coluna 12, Glicerol 2,5 M; Coluna 13, Sacarose 1 M; Coluna 14, cultura total antes da ativação com IPTG.

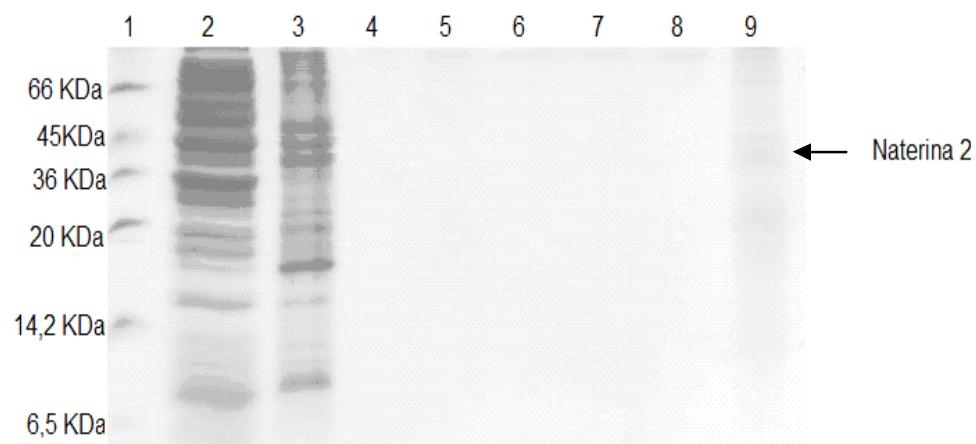

Figura 17: Efeito de efeitos de diferentes pHs na solubilização da proteína Naterina 2. Análise por SDS-PAGE não reduzido da amostra solúvel obtida em tampão de renaturação contendo $10 \mathrm{mM}$ na proporção de 2 GSH:3 GSSG e 1 M GdnHCl, PEG 6000 0,1\%. Coluna 1, Marcador de peso molecular; Coluna 2, Cultura de células sem ativação com IPTG; Coluna 3, Corpos de inclusão (amostra insolúvel), Coluna 4, pH 5,5; Coluna 5, pH 6,5; Coluna 6, pH 7,5; Coluna 7, pH 8,0; Coluna 8, pH 8,5; Coluna 9, pH 9,0. As amostras foram dialisadas em tampão pH 8,0.

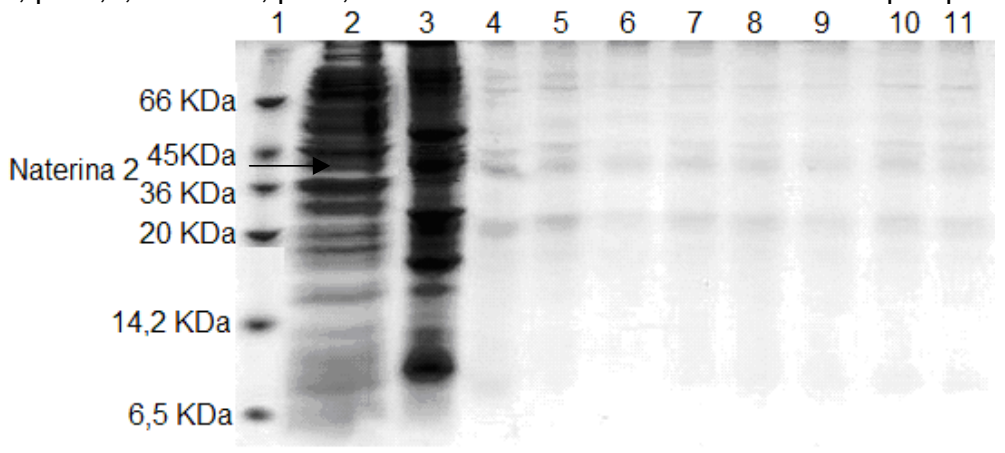


Figura 18: Efeito de efeitos de diferentes D.O.s na solubilização da proteína Naterina 2. Análise por SDS-PAGE não reduzido da amostra solúvel obtida em tampão de renaturação contendo 10 mM na proporção de 2 GSH:3 GSSG pH 9,0 e 1 M GdnHCl, PEG 6000 0,1 \%. Coluna 1, Marcador de peso molecular; Coluna 2, Cultura de células sem ativação com IPTG; Coluna 3, Corpos de inclusão (amostra insolúvel); Coluna 4, D.O. 2; Coluna 5, D.O. 4; Coluna 6, D.O. 6; Coluna 7, D.O. 8; Coluna 8, D.O. 10; Coluna 9, D.O. 12; Coluna 10, D.O. 14; Coluna 11, D.O. 16.

\subsubsection{Condição final}

A Figura 19 mostra um gel de eletroforese de todas as fases da obtenção de Naterina 2, solúvel. Conforme se pode observar na coluna 8 desta figura, a amostra que não foi submetida à pressão e foi mantida em pressão atmosférica não foi renaturada. O rendimento de renaturação da naterina foi de $20 \%$ a partir de proteína insolúvel (corpos de inclusão) e foram obtidas $3,7 \mathrm{mg}$ de Naterina renaturada/L de cultura bacteriana.

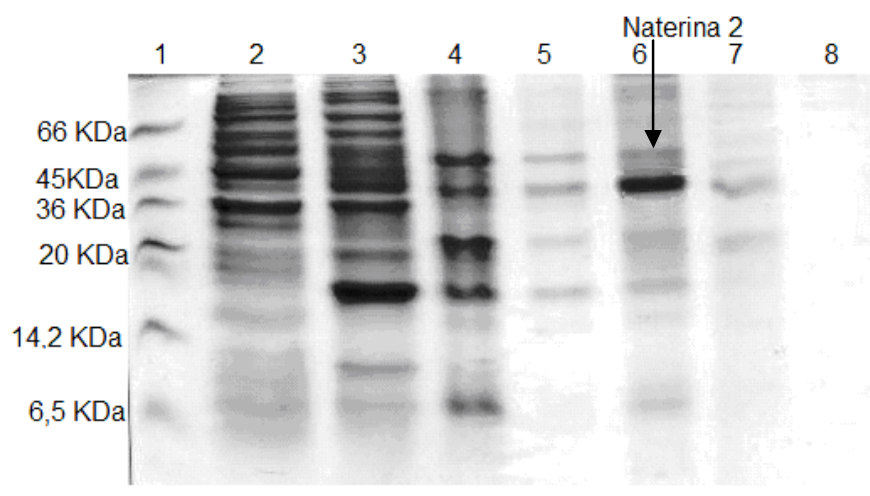

Figura 19: Gel de eletroforese com todas as fases da renaturação. Análise por SDS-PAGE não reduzido de Naterina 2 solúvel obtida em tampão de renaturação contendo $10 \mathrm{mM}$ na proporção de 2 GSH:3 GSSG e $1 \mathrm{M}$ GdnHCl pH 9,0 e corpos de inclusão na D.O. 6, com rendimento de $20 \%$. Coluna 1, marcador de peso molecular; Coluna 2, bactéria total antes da ativação com IPTG; Coluna 3, bactéria total após a ativação com IPTG; Coluna 4, Corpos de inclusão (amostra insolúvel); Coluna 5, amostra insolúvel após a pressurização; Coluna 6, amostra insolúvel após diálise; Coluna 7, amostra pressurizada e dialisada; Coluna 8 , amostra mantida a pressão atmosférica após a diálise.

A Figura 20 mostra fotografias em microscopia eletrônica de varredura das amostras insolúveis: corpos de inclusão (Figura $7 \mathrm{~A}$ ), fração insolúvel dos corpos de inclusão de Naterina 2 pressurizados (Figura 7B) e também os agregados formados após diálise (Figura $7 \mathrm{C}$ ). Nesta figura pode-se observar que os agregados formados após a pressurização possuem morfologia muito diferente daquela dos corpos de inclusão, indicando que houve a solubilização desses agregados durante a pressurização e que provavelmente ocorreu a reagregação no retorno à pressão atmosférica. 
A

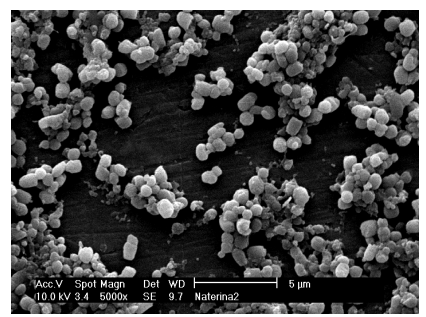

B

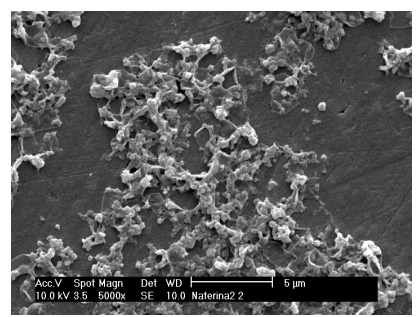

C

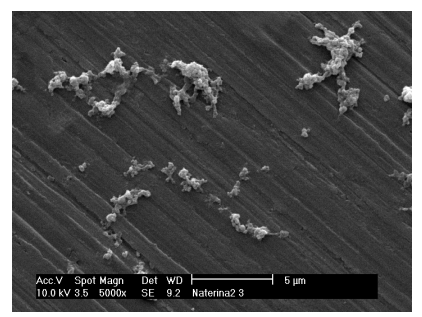

Figura 20: Microscopia eletrônica de varredura (MEV) das diferentes fases do processo de renaturação. A, corpos de inclusão antes da pressurização; $B$, corpos de inclusão após a pressurização; C, agregados formados após a diálise.

O ensaio de microscopia intravital mostrou o aumento de linfócitos nas vênulas e também a presença de trombos, sintomas que provavelmente se devem à presença de contaminantes bacterianos. Porém, um sintoma característico da Naterina, que consiste na constrição de arteríolas foi observado. A figura 21 mostra vênulas e arteríolas antes da aplicação da proteína. A figura 22 mostra a fotografia do tecido do camundongo 15 minutos após a aplicação da amostra controle (amostra solúvel de lisado de E. coli sem o gene e tratada do mesmo modo que a Naterina 2 solúvel). A figura 23 mostra o tecido do camundongo após a aplicação da amostra contendo Naterina 2 recombinante solúvel e pode-se observar que houve a contração de arteríolas (fotografias A e B), após 5 minutos, cuja ação provavelmente se deve à ação desta proteína recombinante. Houve reversão deste sintoma, conforme se pode observar na Figura 21C após 15 minutos.

A

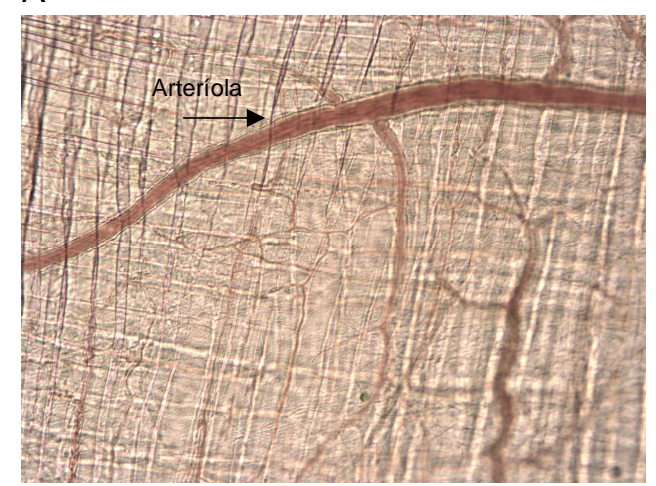

Figura 21: Fotografias do tecido murino antes da aplicação da amostra, $A$, arteríolas e B, vênulas.
B

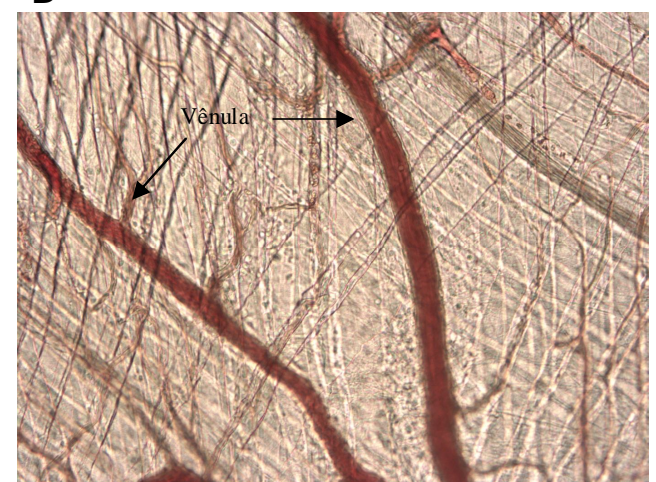

B 

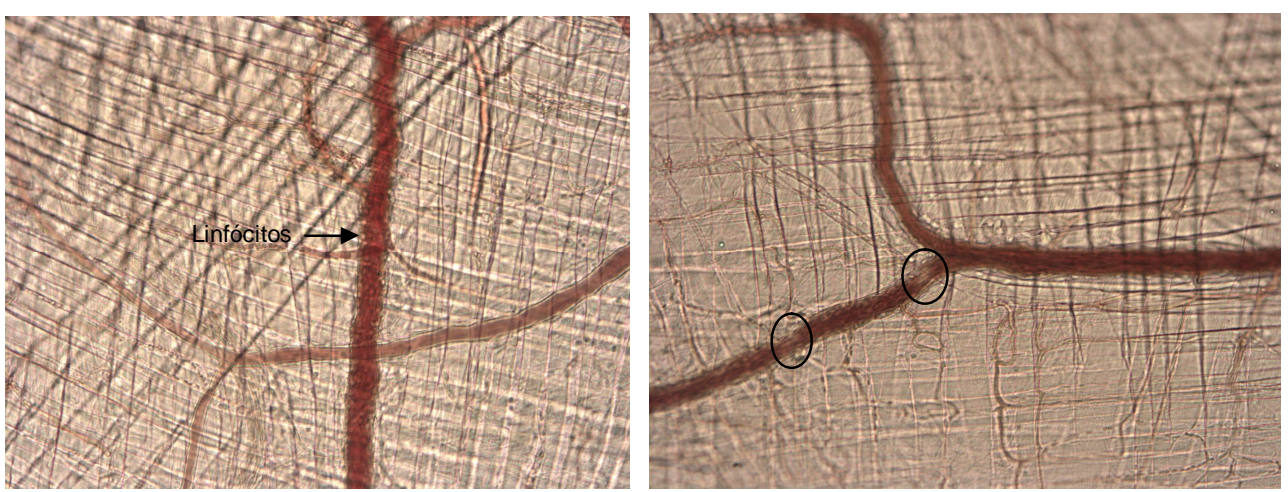

Figura 22: Fotografias do tecido murino após a aplicação da amostra controle. A, rolamento de linfócitos e B, presença de trombos.

A

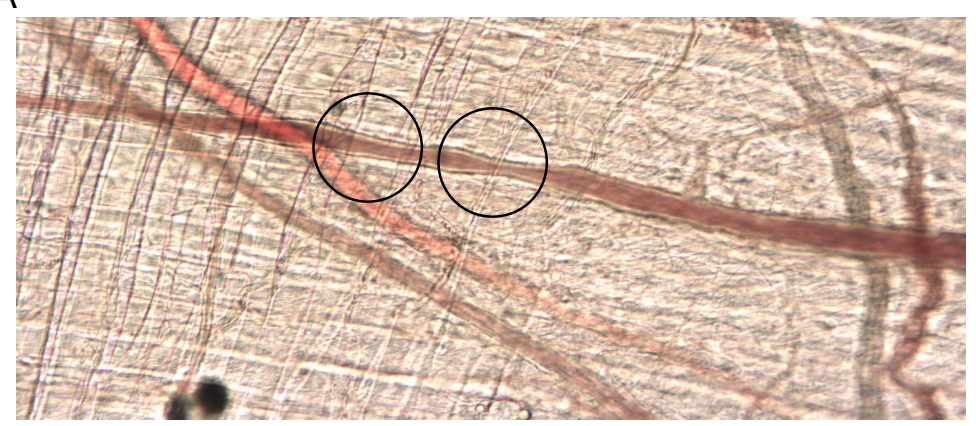

B
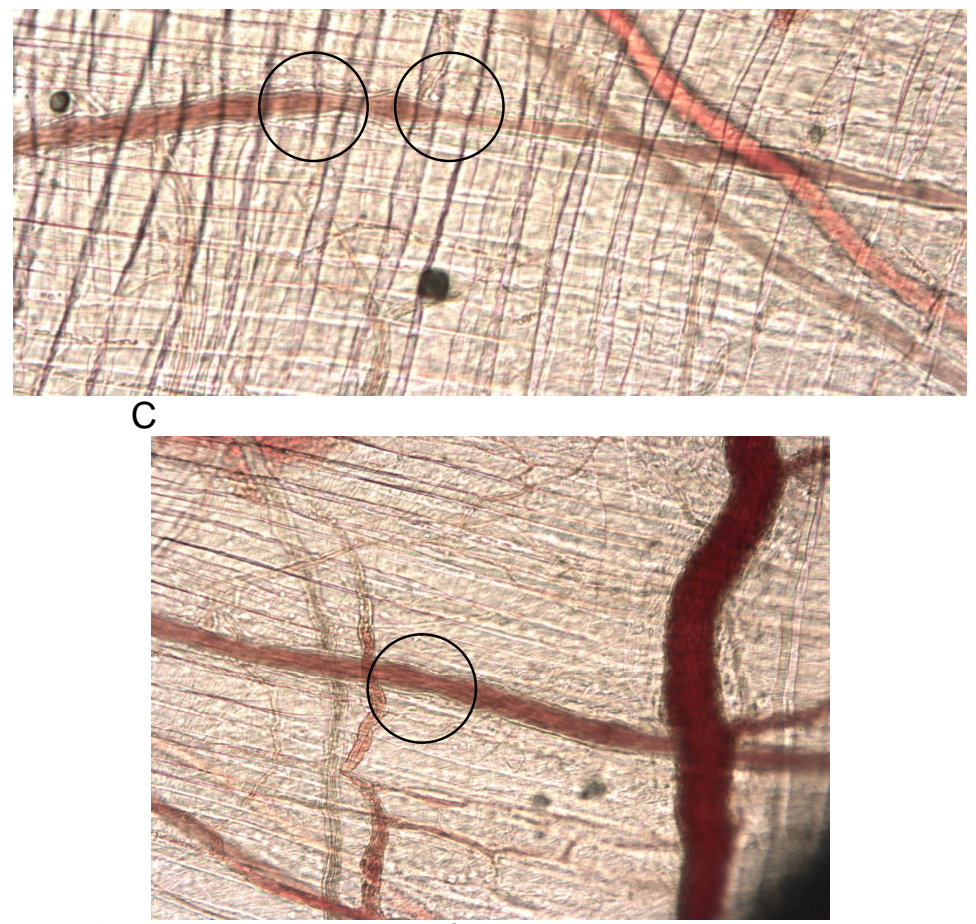

Figura 23: Fotografias do tecido murino após a aplicação da amostra de Naterina 2. A e B, contração de arteríolas após 5 minutos da aplicação da amostra; e C, descontração da arteríola após 15 minutos. 


\subsection{Bothropstoxina 1}

\subsubsection{Determinação das condições de pressurização}

As Figuras 24 a 29 mostram géis de eletroforese de poliacrilamida de amostras de Bothropstoxina 1 pressurizadas em 2000 bar por 16 horas em diversas condições de tampão de renaturação. Após a pressurização as amostras foram centrifugadas e a seguir dialisadas para retirada do $\mathrm{GdnHCl}$. Nas figuras 24 e 25 podemos observar que foi obtido melhor rendimento de Bothropstoxina 1 solúvel quando o par redox foi utilizado no tampão de renaturação na proporção de 2 GSH: 3 GSSG (Figura 24, coluna 5) na concentração total de $3 \mathrm{mM}$ de (Figura 25, coluna 6).

A Figura 26 mostra que a concentração de $\mathrm{GdnHCl}$ na qual se obteve maior concentração de Bothropstoxina 1 solúvel foi a de $2 \mathrm{M}$ (coluna 8 ). $\mathrm{O} \mathrm{pH}$ de renaturação escolhido foi de 7,5 (coluna 5 da Figura 27). A figura 28 demonstra que a presença dos aditivos não levou à obtenção de melhores rendimentos de renaturação. A figura 29 mostra que os rendimentos de Bothropstoxina 1 solúveis foram proporcionais à diluição das amostras e que portanto, a condição de menor concentração estudada (D.O. $=0,5)$ foi a escolhida (Figura 29, coluna 3). O rendimento de renaturação foi de $30 \%$.

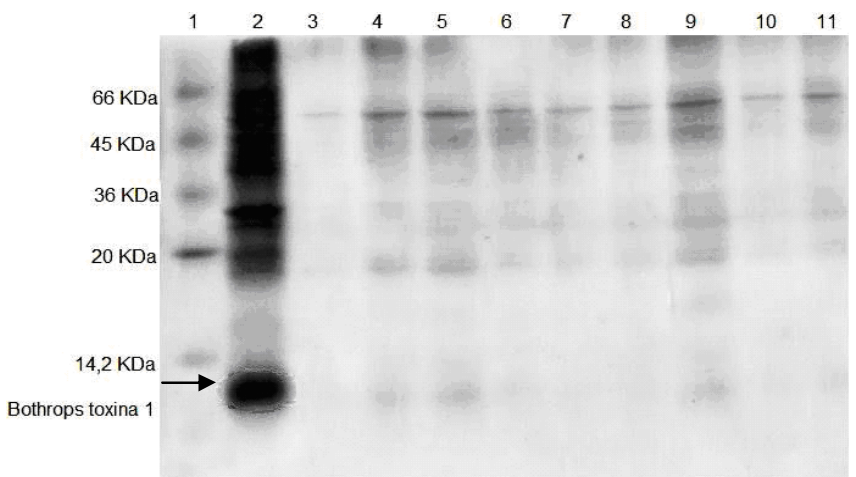

Figure 24: Efeito de diferentes proporções de glutationas oxidada: reduzida na solubilização da proteína Bothropstoxina 1. Análise por SDS-PAGE reduzido da toxina solúvel obtida em tampão de renaturação contendo $2 \mathrm{M}$ de $\mathrm{GdnHCl}$ e concentração de glutationas oxidada e reduzida de $10 \mathrm{mM}$ e pH 7,5. Coluna 1, Marcador de peso molecular; Coluna 2, Corpos de inclusão (amostra insolúvel); Coluna 3, GSH 1:9 GSSG; Coluna 4, GSH 1:4 GSSG; Coluna 5, GSH 2:3 GSSG; Coluna 6, GSH 1:2 GSSG; Coluna 7, GSH 1:1 GSSG; Coluna 8, GSH 2:1 GSSG; Coluna 9, GSH 3:2 GSSG; Coluna 10, GSH4:1 GSSG; Coluna 11, GSH 9:1 GSSG. 


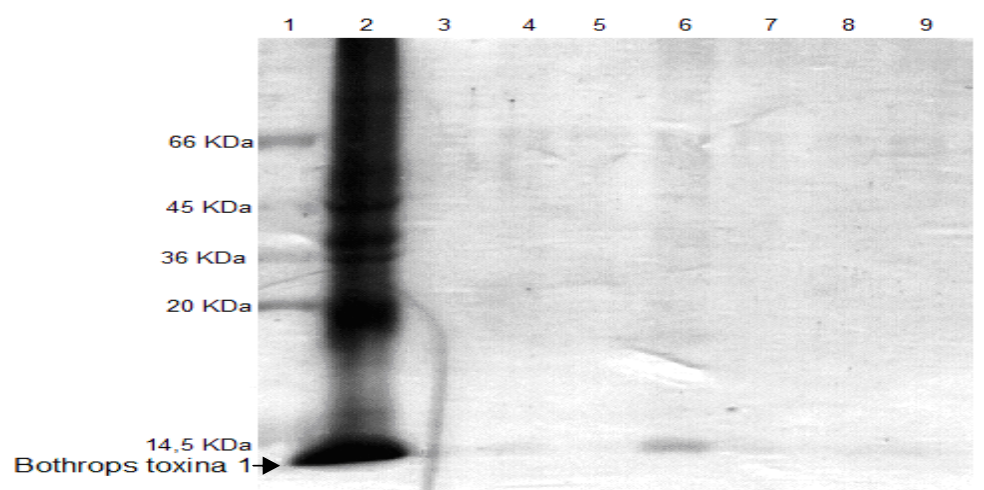

Figure 25: Efeito de diferentes concentrações finais de glutationas oxidada: reduzida em proporção 2:3 na solubilização da proteína Bothropstoxina 1. Análise por SDS-PAGE reduzido da toxina solúvel obtida em tampão de renaturação contendo $2 \mathrm{M}$ de $\mathrm{GdnHCl}$ e pH 7,5. Coluna 1, Marcador de peso molecular; Coluna 2, Corpos de inclusão (amostra insolúvel); Coluna 3, 0 mM de GSH/GSSG; Coluna 4, 0,7 mM de GSH/GSSG; Coluna 5, 1,5 mM de GSH/GSSG; Coluna 6, 3 $\mathrm{mM}$ de GSH/GSSG; Coluna 7, 6 mM de GSH/GSSG; Coluna 8, 10 mM de GSH/GSSG; Coluna 9, $20 \mathrm{mM}$ de GSH/GSSG.

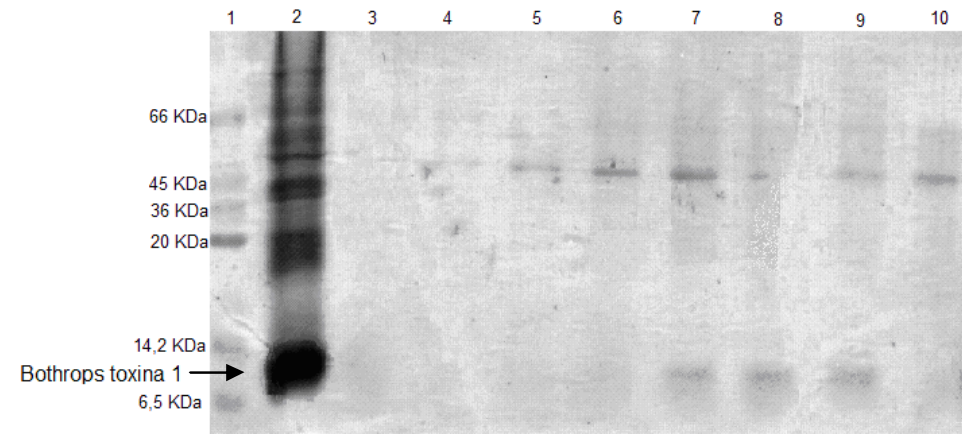

Figure 26: Efeito de diferentes concentrações finais $\mathrm{GdnHCl}$ na solubilização da proteína Bothropstoxina 1. Análise por SDS-PAGE reduzido da Bothropstoxina 1 solúvel obtida em tampão de renaturação contendo $3 \mathrm{mM}$ na proporção de $1 \mathrm{GSH}: 2$ GSSG pH 7,5. Coluna 1 Marcador de peso molecular; coluna 2, Corpos de inclusão (amostra insolúvel); coluna 3, $0 \mathrm{M} \mathrm{GdnHCl;} \mathrm{coluna} \mathrm{4,}$ 0,25 M GdnHCl; coluna 5, 0,5 M GdnHCl; coluna 6, 0,75 M GdnHCl; coluna 7, $1 \mathrm{M} \mathrm{GdnHCl}$; coluna 8, 2 M GdnHCl,; coluna 9, 4 M GdnHCl; coluna 10, 6 M GdnHCl.

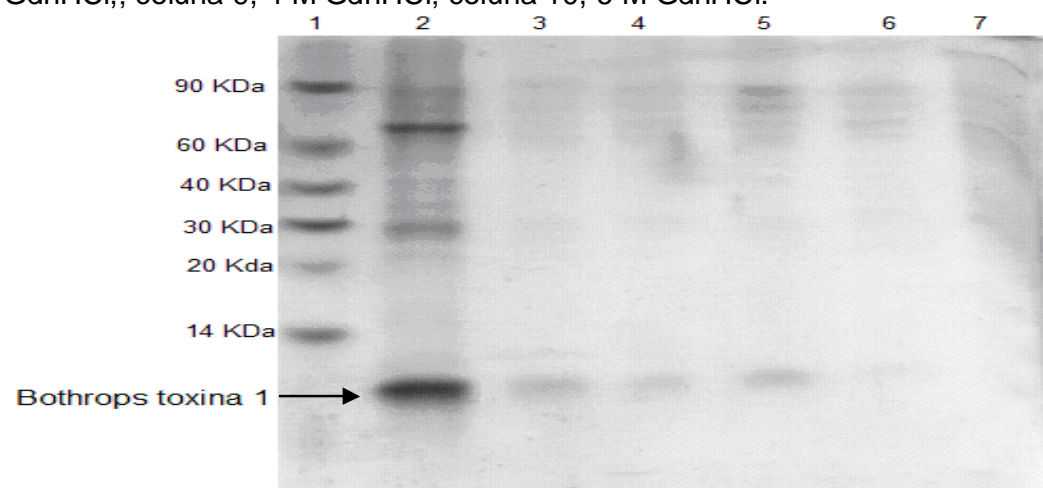

Figure 27: Efeito de diferentes pHs na solubilização da proteína Bothropstoxina 1. Análise por SDS-PAGE reduzido da Bothropstoxina 1 solúvel obtida em tampão de renaturação contendo 3 $\mathrm{mM}$ na proporção de $2 \mathrm{GSH}: 3 \mathrm{GSSG}$ e $2 \mathrm{M} \mathrm{GdnHCl}$. As amostras foram dializadas em tampão $\mathrm{pH}$ 7,5. Coluna 1, marcador de peso molecular; coluna 2, corpos de inclusão (amostra insolúvel); 
coluna 3; Tris $\mathrm{HCl} \mathrm{pH} \mathrm{5,5;} \mathrm{coluna} \mathrm{4,} \mathrm{Tris} \mathrm{HCl} \mathrm{pH} \mathrm{6,5;} \mathrm{Coluna} \mathrm{5,} \mathrm{Tris} \mathrm{HCl} \mathrm{pH} \mathrm{7,5;} \mathrm{Coluna} \mathrm{6,} \mathrm{Tris} \mathrm{HCl}$ $\mathrm{pH} 8,5$; Coluna 7, Tris $\mathrm{HCl} \mathrm{pH} \mathrm{9,0.}$

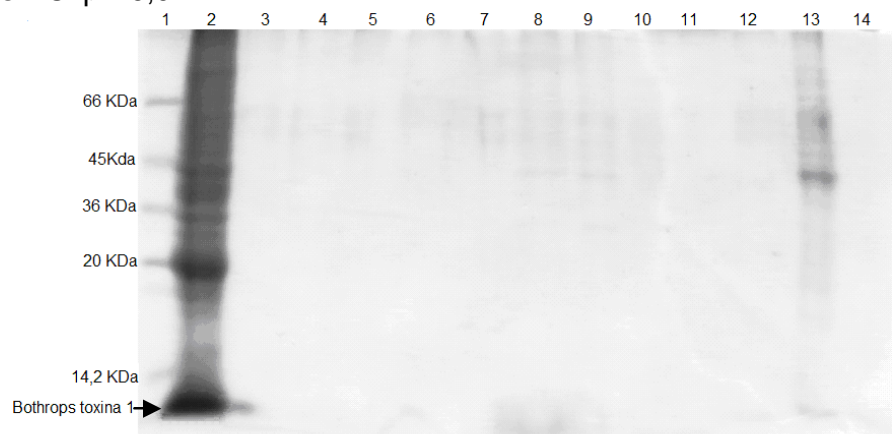

Figura 28: Efeito de efeitos de diferentes aditivos na solubilização da proteína Bothropstoxina 1. Análise por SDS-PAGE reduzido da amostra solúvel obtida em tampão de renaturação contendo 3 mM na proporção de 2 GSH:3 GSSG pH 7,5 e 2 M GdnHCl. Coluna 1, Marcador de peso molecular; Coluna 2, Corpos de inclusão (amostra insolúvel); Coluna 3, sem aditivos; Coluna 4, $\mathrm{NaCl}$ 0,15 M; Coluna 5, L-Arginina 0,5 M; Coluna 6, PEG 6000 0,1\%; Coluna 7, Glicose 1M; Coluna 8, Glicerol 2,5 M; Coluna 9, Sacarose 1 M; Coluna 10, Surfaína 1\%; Coluna 11, Surfaína 0,1\%; Coluna 12, Tween 20 0,1 mM; Coluna 13, Triton X-100 0,5 mM,

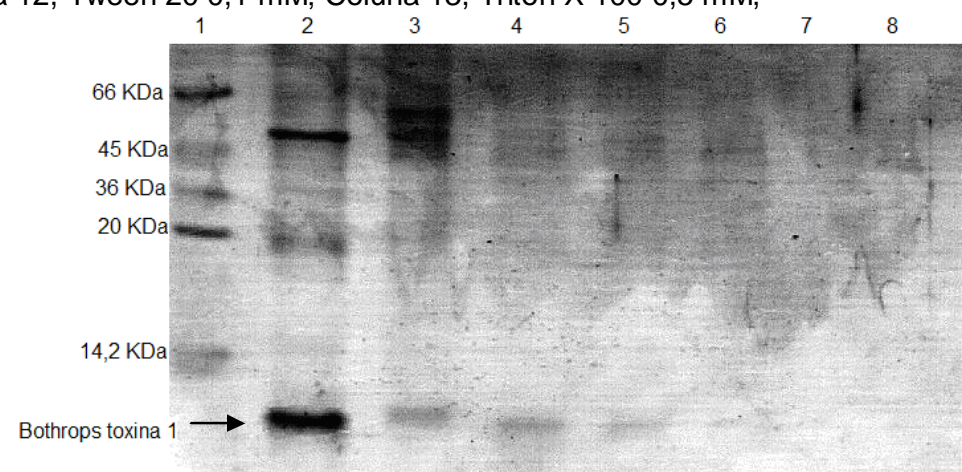

Figura 29: Efeito de diferentes DO s no rendimento de renaturação de Bothropstoxina 1. Análise por SDS-PAGE reduzido de Bothropstoxina 1 solúvel obtida em tampão de renaturação contendo 3 mM na proporção de 2 GSH:3 GSSG e 2 M GdnHCl pH 7,5. Coluna1) Marker; Coluna 2) Corpos de inclusão (amostra insolúvel) na concentração de 0,5 DO; Coluna 3) 0,5 DO; Coluna 4) 1,0 DO; Coluna5) 2,0 DO; Coluna 6) 4,0 DO; Coluna 7) 6,0 DO; e, Coluna 8) 8,0 DO.

\subsubsection{Condição final}

A Figura 27 mostra um gel de eletroforese de todas as fases da obtenção de Bothropstoxina 1 solúvel. Conforme se pode observar na coluna 7 desta figura, a amostra mantida em pressão atmosférica não foi renaturada. $O$ rendimento de renaturação da Bothropstoxina 1 foi de $32 \%$, e foram obtidas $9,2 \mathrm{mg}$ de Bothropstoxina 1 renaturada/L de cultura bacteriana. 


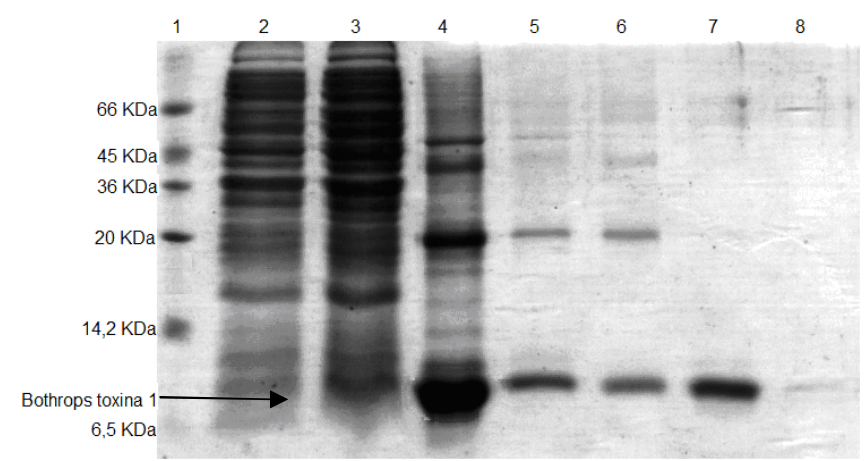

Figura 30: Gel de eletroforese com todas as fases da renaturação. Análise por SDS-PAGE reduzido de Bothropstoxina 1 solúvel obtida em tampão de renaturação contendo $3 \mathrm{mM}$ na proporção de 2 GSH:3 GSSG e $1 \mathrm{M} \mathrm{GdnHCl}$ pH7,5 e corpos de inclusão na DO 0,5, com rendimento de $32 \%$. Coluna 1, marcador de peso molecular; Coluna 2, bactéria total antes da ativação com IPTG; Coluna 3, bactéria total após a ativação com IPTG; Coluna 4, Corpos de inclusão (amostra insolúvel) antes da pressurização; Coluna 5, amostra insolúvel após a pressurização; Coluna 6, amostra insolúvel após a diálise; Coluna 7, amostra pressurizada e dialisada; Coluna 8 , amostra dialisada renaturada em pressão ambiente.

Pela análise por western blot (Figura 31), podemos verificar que houve uma identidade imunológica de Bothropstoxina 1, que apresentou-se como dímero e monômero, aparentemente em grande concentração.

12

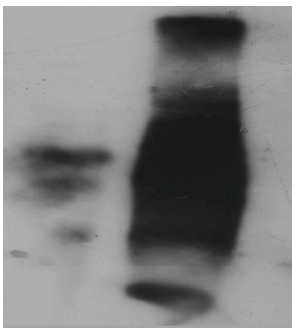

Figura 31: Western blotting de Bothropstoxina 1,. $\mathrm{O}$ anticorpo utilizado foi anti lgG anti mouse. Coluna 1; 1, padrão de Bothropstoxina 1; coluna 2, Bothrops toxina 1.

A

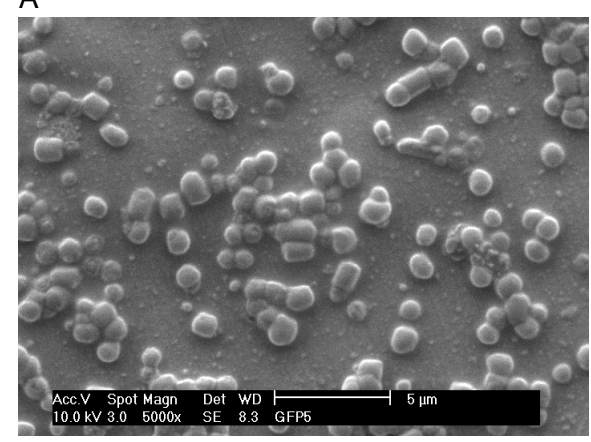

$\mathrm{B}$

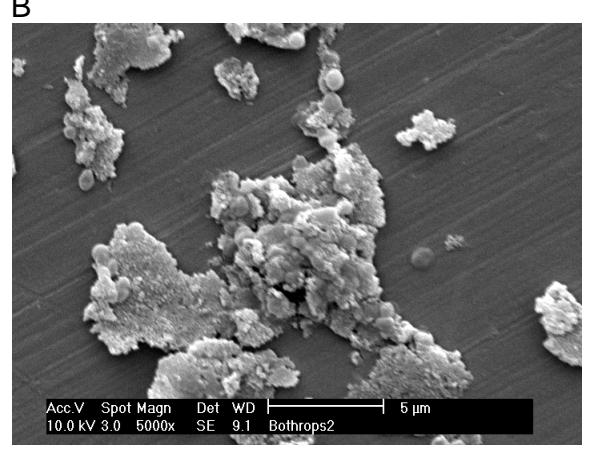

Figura 32: Microscopia eletrônica de varredura (MEV) das diferentes fases do processo de renaturação. A, corpos de inclusão antes da pressurização; B, corpos de inclusão após a | pressurização. Não foi possível a visualização dos agregados após a diálise. 
A Figura 33 mostra fotografias de amostras insolúveis de Bothropstoxina 1 analisadas por microscopia eletrônica de varredura: corpos de inclusão (Figura 32A), fração insolúvel dos corpos de inclusão de Bothrops toxina 1 pressurizados (Figura 32B). Nesta figura pode-se observar que os agregados formados após a pressurização possuem morfologia muito diferente daquela dos corpos de inclusão, indicando que houve a solubilização desses agregados durante a pressurização e que provavelmente ocorreu a reagregação no retorno à pressão atmosférica.

A figura 32 mostra o gráfico de atividade de LDH do sobrenadante de cultura das células $\mathrm{C} 2 \mathrm{C} 12$ tratadas com a toxina, mostrando que a Bothorpstoxina 1 renaturada sob pressão a partir dos corpos de inclusão mostrou atividade citotóxica dose-dependente para a cultura de células $\mathrm{C} 2 \mathrm{C} 12$. A citotoxicidade foi maior para as células diferenciadas do que para as células não diferenciadas.

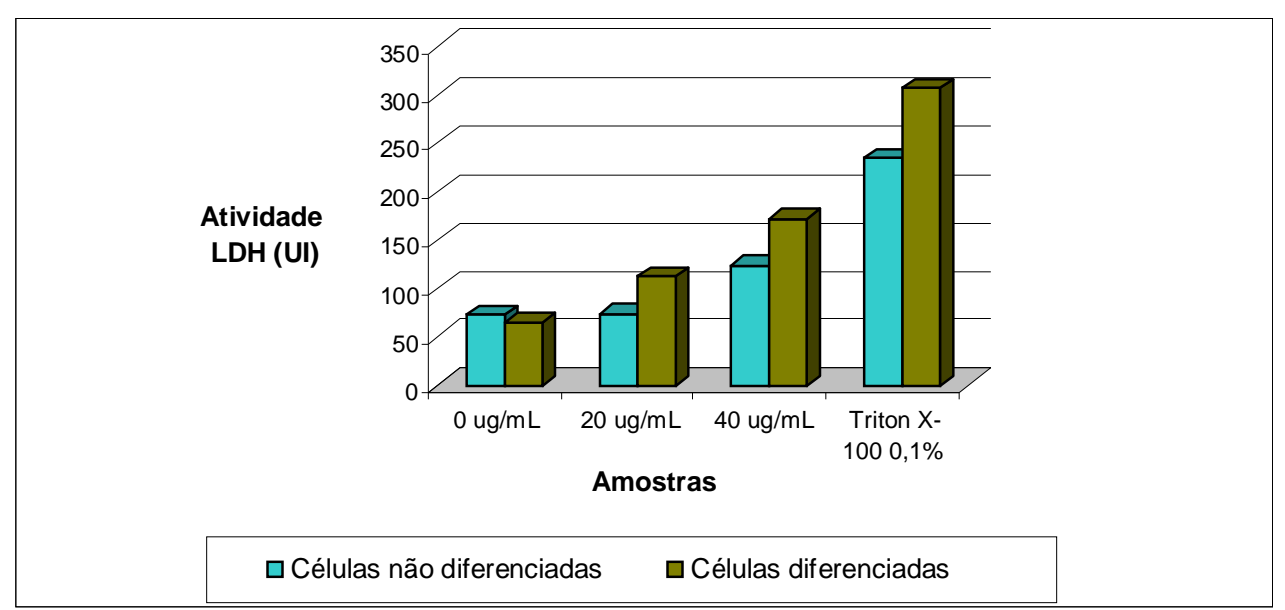

Figura 33: Atividade de LDH do sobrenadante da cultura de células C2C12 tratadas com Bothropstoxina 1 renaturada. 


\section{Discussão}

Neste trabalho foi obtida a solubilização e renaturação, sob condição de alta pressão hidrostática, de três diferentes proteínas a partir de agregados em corpos de inclusão.

Para a realização deste trabalho de renaturação de proteínas agregadas em corpos de inclusão produzidos em $E$. coli foram escolhidas toxinas com pelo menos 5 pontes dissulfídicas, o que em geral torna difícil sua renaturação. Tentativas anteriores de se tentar obter a renaturação das toxinas NXH8 e Naterina 2 foram infrutíferas, invariavelmente sendo obtidos altos níveis de reagregação com conseqüente formação de agregados insolúveis (Magalhães e cols., 2005; Prieto, 2002). A renaturação da Bothropstoxina 1, no entanto, já foi obtida utilizando processo que inicia com a solubilização desta proteína utilizando altas concentrações de agente desnaturante (Ward, 2001).

A presença de cavidades não expostas à água nas proteínas no estado agregado faz com que estas apresentem maior volume do que essas mesmas proteínas no estado nativo ou desnaturado (Silva e cols., 2006). Em pressões da ordem de 1000 a 3000 bar são favorecidos os estados protéicos contendo espaços de cavidades mínimos, ou seja, proteínas no estado nativo ou desnaturado seriam favorecidas sobre estruturas agregadas. Pressões moderadas (1000-3000 bar) são geralmente efetivas para a dissociação de oligômeros e agregados protéicos enquanto pressões hidrostáticas maiores (> 3000 bar) são tipicamente requeridas para a desnaturação de proteínas (Kim e cols., 2006).

O primeiro problema a ser resolvido para obtermos a renaturação de uma proteína a partir de agregados solúveis é a solubilização desta suspensão e isto pode ser obtido pela utilização de altas pressões, auxiliadas pela presença de agentes desnaturantes, geralmente em baixas concentrações. Foi demonstrado 
que pontes de hidrogênio não nativas entre moléculas nos agregados, as quais são insensíveis à aplicação de pressão, interferem com a dissolução induzida pela pressão e que a presença de $\mathrm{GdnHCl}$ ou uréia em concentrações subdesnaturantes pode auxiliar a romper essas pontes e permitir a dissolução dos agregados insolúveis (St John e cols., 2001).

Já foi demonstrada a presença de certa porcentagem de estruturas secundárias e mesmo terciárias semelhantes às nativas em corpos de inclusão bacterianos, concomitantemente com proteínas sem conformação (Tsumoto e cols., 2003; Garcia-Fruitos e cols., 2007). A utilização de altas concentrações de agentes desnaturantes para a solubilização de proteínas recombinantes durante processos de renaturação de proteínas induz a desnaturação, perda de estrutura, e por isso durante a remoção do agente desnaturante, para obtenção do enovelamento das proteínas, geralmente ocorre reagregação. (Middelberg, 2002). Além disso, tem sido demonstrado que a utilização de condições brandas de solubilização dos corpos de inclusão favorecem a manutenção das estruturas nativas, favorecendo o enovelamento e a renaturação de proteínas recombinantes (Singh, 2005, Patra, 2000; St. John, 2001).

Devido ao fato de altas pressões favorecerem a desagregação de proteínas, no caso de renaturação nessas condições foi necessária a utilização de concentrações de $\mathrm{GdnHCl}$ bem menores do que aquelas normalmente utilizadas para a solubilização de corpos de inclusão em pressão atmosférica. A presença de $\mathrm{GdnHCl}$ se mostrou indispensável para a renaturação das três toxinas aqui estudadas. As molaridades mínimas de $\mathrm{GdnHCl}$ utilizadas por nós foram de $2 \mathrm{M}$ para NXH8 e 1M para Naterina 2. Para a Bothropstoxina1 a molaridade mínima de GdnHCl também foi de $1 \mathrm{M}$.

Nas três toxinas estudadas foram realizados controles em que as mesmas amostras foram submetidas à pressurização foram também mantidas sob pressão atmosférica, tendo sido obtidos sempre níveis de proteínas solúveis muito abaixo do que aqueles obtidos para as amostras pressurizadas.

A aplicação de 2000 bar de pressão em agregados de NXH8 em corpos de inclusão em solução contendo $1 \mathrm{M}$ de $\mathrm{GdnHCl}$ foi o suficiente para que o espalhamento de luz, medido em fluorímetro em 320 nm, caísse em 72,9\%, (quando comparado com o espalhamento de luz em pressão atmosférica e na ausência de guanidina) e estabilizasse em 30 min após a aplicação da pressão, 
indicando que somente $27,1 \%$ dos agregados não foram solubilizados durante a pressão (dados não mostrados).

Pela técnica de renaturação convencional se utilizam pares oxidoredutores, os quais possibilitam que as pontes dissulfeto se rompam e se formem de forma dinâmica durante o enovelamento das proteínas que possuem pontes dissulfeto (St John e cols., 2002; Drevet e cols., 1997). O par redox também se mostrou fundamental para a recuperação das proteínas estudadas neste trabalho, durante o processo de renaturação, o que era esperado, tendo em vista que as três toxinas apresentam várias pontes dissulfeto. As concentrações ótimas do par redox variaram entre 3, 6 e 10 mM e proporções de GSH 1:4 GSSG e 2 GSH:3 GSSG. A proporção de 2GSH: 3GSSG em concentração de $3 \mathrm{mM}$ foi estabelecida para renaturação da Bothropstoxina 1. Ward e cols descreveram proporção semelhante desses reagentes (1GSH:1GSSG), em concentração de $8 \mathrm{mM}$ para a renaturação desta proteína utilizando processo tradicional, em pressão atmosférica (Ward, 2001).

$\mathrm{O}$ pH do tampão utilizado para renaturação também é crítico para que a reação de oxidação/redução ocorra. Normalmente pHs alcalinos favorecem a formação de pontes dissulfídicas nativas (Clark, 2001), pois permitem a formação e quebra de pontes dissulfídicas (Gilbert, 1995). O pH alcalino (8-9) promove a formação do ânion tiolato e assim a troca das pontes dissulfeto (Middelberg, 2002). pHs alcalinos foram utilizados para as três proteínas testadas. $\mathrm{O}$ pH de 9,0 foi selecionado para a renaturação das toxinas NXH8 e Naterina 2. Para Bothropstoxina $1 \mathrm{opH}$ de 7,5 foi selecionado. E apesar de do fato da literatura existente dizer que para minimizar a agregação durante a renaturação, o pH da solução deve estar entre 1 ou 2 unidades de $\mathrm{pH}$ abaixo ou acima do ponto isoeléltrico $(\mathrm{PI})$ da proteína, para duas das três toxinas solubilizadas neste estudo, foi utilizado um tampão de renaturação com $\mathrm{pH}$ próximo ao $\mathrm{PI}$ da proteína, sendo estas a Bothropstoxina $1(\mathrm{PI}=8,2)$ e a Naterina $2(\mathrm{PI}=8,5)$.

A presença de aditivos como o aminoácido L-arginina, açúcares e polióis pode ser uma ferramenta muito útil para modular a termodinâmica e cinética de reações de proteínas e agregados protéicos, tanto em condições de pressão atmosférica quanto sob altas pressões (Clark, 2001; Kim e cols., 2006).

Houve um pequeno acréscimo de rendimento de NXH8 e Bothropstoxina 1 solúvel quando se adicionou o detergente surfaína. No entanto, preferimos não 
utilizar este reagente pelo fato de os detergentes serem usualmente de difícil separação da proteína de interesse, mesmo após realização de diálise. A presença de PEG 6000 se mostrou bastante útil para a elevação dos rendimentos de Naterina 2 solúvel e foi utilizado nos experimentos subsequentes.

$\mathrm{O}$ ensaio de Western blotting mostrou que a Bothropstoxina 1 e NXH8 apresentam identidade imunológica. A NXH8 se apresentou como monômero, dímero e trímero sob condições não redutoras. Sob condições redutoras a proteína apresentou uma menor migração no SDS-PAGE, o que é uma indicação da presença de pontes dissulfídicas na proteína renaturada. A Bothropstoxina 1 apresentou-se também como monômero e dímero.

A concentração de proteínas pode também ser um parâmetro importante para correta renaturação, que compete com os caminhos de agregação e de formação de estrutura incorreta (Randolph e cols., 2002). Alguns artigos demonstraram que a concentração de proteínas necessária para renaturação sob altas pressões pode ser de uma a duas ordens de grandeza maior que aquelas comumente utilizadas para renaturação tradicional onde a concentração inicial das proteínas varia de 10-50 ug/mL (Phelps, 2007, St John e cols., 1999; Singh e Panda, 2005). Este foi o caso para a Naterina 2, onde não se observou diferença nos rendimentos desta proteína solubilizada nas D.O.s testadas. Para as proteínas NXH8 e Bothrops toxina 1 o rendimento de obtenção foi maior em condições de menor concentração protéica (0,5 de DO).

Nas fotografias dos agregados protéicos analisados em MEV, podemos observar que o formato dos corpos de inclusão das proteínas NXH8 e Naterina 2 sofreram modificação durante as etapas da pressurização, passando de formas bem definidas antes da pressurização, a agregados disformes indicando que as proteínas foram parcialmente solubilizadas, mas que nem toda proteína adquiriu o enovelamento nativo. Na última etapa, após a diálise, os agregados se apresentaram em grumos indicando que as proteínas que não sofreram a renaturação correta, voltaram a se agregar quando foram retirados os agentes desnaturantes.

Foi observado, por análise de florescência, um deslocamento do pico máximo de emissão de triptofano da NXH8 solúvel, renaturada sob pressão na presença de concentrações crescentes de uréa, indicando maior exposição do aminoácido triptofano, o que é uma indicação de que se trata de uma proteína 
com estrutura terciária adequada. O espectro de dicroísmo circular apresentou um pico negativo em torno de $200 \mathrm{~nm}$ e positivo em $190 \mathrm{~nm}$ em todas as temperaturas analisadas. Os espectros de proteínas compostas exclusivamente de folhas beta, apresentam baixa intensidade e exibem uma variedade de formatos com um pico mínimo em 210-220nm e um pico negativo entre 170 e 180 $\mathrm{nm}$, passando para positivo em $185 \mathrm{~nm}$. No entanto, foi descrito que algumas proteínas com este tipo de estrutura apresentam um modelo de espectro característico de proteínas sem conformação, como por exemplo a elastase e a alfa quimiotripsina (Hennessey e Johnson, 1981). A estrutura cristalográfica destas proteínas mostra que estas folhas antiparalelas dobradas possuem formas muito distorcidas ou formam pequenas cordas irregulares. Estas irregularidades podem causar um pico de CD negativo na região de 200 nm (Manavalan e Jonhson, 1983). Por isso, não pudemos comprovar por análise de dicroísmo circular se a estrutura secundária de folhas beta da NXH8 está corretamente formada. A análise de dicroísmo circular, com a variação da temperatura, mostra que houve mudança de estrutura secundária da NXH8 pela elevação da temperatura. Devido ao fato de desconhecermos se existe e qual seria a atividade biológica da NXH8, também não pudemos comprovar se a proteína solubilizada possui alguma atividade. A proteína solubilizada pela aplicação de altas pressões se mostrou estável, sem sinal de reagregação, inclusive durante a purificação em resina de afinidade por metais imobilizados e análise em cromatografia de exclusão molecular (HPLC).

Em ensaio biológico, no qual se utilizou a Naterina 2 renaturada sob altas pressões a toxina se mostrou ativa em ensaio de microscopia intravital, causando uma contração em vênulas, bem como o aparecimento, rolamento e fixação de linfócitos nos vasos. Estes mesmos fenômenos também foram descritos na presença do veneno total do niquim (dados não mostrados), indicando que a Naterina 2 renaturada sob pressão possui atividade biológica semelhante àquela nativa, presente no veneno de ninquim. A presença de trombos foi verificada na amostra de naterina renaturada mas também foi observada na presença de amostra controle.

A Bothropstoxina 1 apresenta uma estrutura tridimensional idêntica à das fosfolipases A2 de classe II, no entanto, devido a uma mutação, com a substituição do ácido aspártico 49K, pela lisina, esta proteína é incapaz de se ligar 
ao $\mathrm{Ca} 2+$, e portanto é desprovida de atividade catalítica do fosfolípede e por isso não utilizamos ensaio de atividade fosfolipásica para determinação de atividade desta toxina. Ensaios de detecção de LDH na cultura de miotúbulos ou de mioblastos tratados com Bothropstoxina 1 foram realizados. Os resultados obtidos demonstraram que a proteína renaturada sob pressão apresentou atividade citolítica, sugerindo que o tratamento levou à formação de Bothropstoxina 1 com estrutura biofuncional.

A renaturação de proteínas de agregados em corpos de inclusão é um problema relevante tanto científica quanto economicamente, uma vez que corpos de inclusão são um produto muito comum quando se usa a técnica de DNA recombinante para a expressão de proteínas.

A utilização de altas pressões hidrostáticas como uma ferramenta para obtenção de renaturação de proteínas agregadas é um processo relativamente novo e pouco estudado, com pouquíssimos casos na literatura, o que coloca o presente trabalho como original e inovador.

Considerando que nunca foi descrito processo de renaturação de duas das três toxinas estudadas (Naterina 2 e NXH8) e que as três toxinas apresentam várias pontes dissulfeto, fator que dificulta em muito o processo de renaturação, a obtenção de rendimentos satisfatórios: $28,6 \mathrm{mg}$ de NXH8/L de cultura, 3,7 mg de Naterina 2/L de cultura e 9,2 mg de Bothropstoxina 1/L de cultura (20 a 40\% a partir de corpos de inclusão) de proteínas solúveis e com atividade biológica é um resultado de muita relevância. 


\section{Referências Bibliográficas}

AMI, D., A.; NATALELLO, Structural analysis of protein inclusion bodies by Fourier transform infrared microspectroscopy. Biochim Biophys Acta.. v. 1764(4). p. 7939, 2006.

ARAKAWA, T., I. KATSUYAMA. A magic agent in protein refolding: arginine Tanpakushitsu Kakusan Koso, v. 48(16), p 2310-7, 2003.

ARAKAWA, T. AND S. N. TIMASHEFF. Preferential interactions of proteins with salts in concentrated solutions. Biochemistry, v. 21(25), p. 6545-52, 1982.

ARAKAWA, T. AND S. N. TIMASHEFF. Stabilization of protein structure by sugars Biochemistry, v 21(25), p 6536-44, 1982.

ARAKAWA, T. AND S. N. TIMASHEFF. Preferential interactions of proteins with solvent components in aqueous amino acid solutions. Arch Biochem Biophys, v. 224(1), p. 169-77, 1983.

ARAKAWA, T. AND S. N. TIMASHEFF. The stabilization of proteins by osmolytes. Biophys J, v. 47(3), p 411-4, 1985.

ARNI R.K., WARD R.J.,Phospholipase A2, a structural review, Toxicon, v. 34(8), p. $827-841,1996$

BAJORUNAITE, E., J. SEREIKAITE. L-arginine suppresses aggregation of recombinant growth hormones in refolding process from $\mathrm{E}$. coli inclusion bodies. Protein J, v. 26(8), p. 547-55, 2007

BOUROT, S., O. SIRE. Glycine betaine-assisted protein folding in a lysA mutant of Escherichia coli. J Biol Chem, v 275(2), p 1050-6, 2000

BOWDEN, G. A., A. M. PAREDES. Structure and morphology of protein inclusion bodies in Escherichia coli. Biotechnology (N Y), v 9(8), p 725-30, 1991. 
BRADFORD M.M., A rapid and sensitive method for the quantitation of microgram quantities of protein utilizing the principle of Protein-Dye Binding, Analytical Biochemistry, v, 72, p 248-254, 1976.

CARREDANO, E.; WESTERLUND, B.; PERSSON, B.; SAARINGEN, M.; RAMASWAMY, S.; EAKER, D. \& EKLUND, H.-The tridimensional structures of two toxins from snake venom throw light on the anticoagulant and neurotoxic sites of phospholipase A2. Toxicon, $\underline{36}$ (1):75-92,1998.

CHURA-CHAMBI, R. M., L. A. GENOVA. (2008). Refolding of endostatin from inclusion bodies using high hydrostatic pressure. Anal Biochem, v 379(1), p 32-9, 2008]

CINTRA, A.C.O.; MARANGONI, S.; OLIVEIRA, B. \& GIGLIO, J.R.-Bothropstoxin-I: amino acid sequence and function. J. Protein Chem., 12 (1):57-64, 1993.

CINTRA, A. C., S. V. SAMPAIO. Assignment of the disulfide bridges in bothropstoxin-I, a myonecrotic Lys49 PLA2 homolog from Bothrops jararacussu snake venom. J Protein Chem, v 20(5), p 377-82, 2001

CLARK, E. D. Protein refolding for industrial processes. Curr Opin Biotechnol, v 12(2), p 202-7, 2001

CLARK, E. D. B. Refolding of recombinant proteins. Curr Opin Biotechnol, v.9(2), p 157-63,1998.

CORDEIRO, Y., L. M. LIMA. Modulation of prion protein oligomerization, aggregation, and beta-sheet conversion by 4,4'-dianilino-1,1'-binaphthyl-5,5'sulfonate (bis-ANS). J Biol Chem, v 279(7), p 5346-52, 2004

DE BERNARDEZ CLARK, E., D. HEVEHAN Oxidative renaturation of hen eggwhite lysozyme. Folding vs aggregation. Biotechnol Prog, v 14(1): 47-54, 1998

DE GROOT, N. S. AND S. VENTURA. Effect of temperature on protein quality in bacterial inclusion bodies. FEBS Lett, v 580(27), p 6471-6, 2006

Formatado: Sueco (Suécia)

DESAI, A., C. LEE, ET AL. Lysozyme refolding with cyclodextrins: structure-activity relationship. Biochimie, v 88(10), p 1435-45, 2006.

ERSOY, M., S. MATIC. On-column refolding of corticotropin-releasing factor receptor 1 extracellular domain by size exclusion chromatography Biomed Chromatogr, 2009.

FOGUEL, D., C. R. ROBINSON, ET AL. Hydrostatic pressure rescues native protein from aggregates. Biotechnol Bioeng, v 63(5), p 552-8, 1999.

FRANCIS,B.;GUTIERREZ,J.M.; LOMONTE,B \& KAISER,I.I. Myotoxin II from Bothrops asper (terciopelo) venom is a Lysine-49 phospholipase A2 Arch.Biochem. Biophys.,284:352-359,1991. 
GARCIA-FRUITOS, E., A. ARIS, Localization of functional polypeptides in bacterial inclusion bodies. Appl Environ Microbiol, v 73(1), p 289-94, 2007.

GILBERT, H. F. Thiol/disulfide exchange equilibria and disulfide bond stability. Methods Enzymol. v 251, p 8-28, 1995.

GIOTTO, M.T., Estrutura cristalográfica da bothropstoxina 1, uma miotoxina K49, 1996, tese de doutorado, Instituto de física de São Carlos.

GOROVITS, B. M. AND P. M. HOROWITZ. High hydrostatic pressure can reverse aggregation of protein folding intermediates and facilitate acquisition of native structure. Biochemistry, v 37(17),p 6132-5, 1998.

GROSS, M. AND R. JAENICKE. Proteins under pressure. The influence of high hydrostatic pressure on structure, function and assembly of proteins and protein complexes. Eur J Biochem 221(2): 617-30, 1994.

HENNESSEY, J.P.JR.JOHNSON, W.C.JR., Information content in the circular dichroism of proteins, Biochemistry, n. 20, p. 1085-1094, 1981

ITO, J.A., Técnicas espectroscópicas em Biofísica, Caderno de física da UES, v.3(1), p 21-29, 2004

KIM, S. H., Y. B. YAN, Role of osmolytes as chemical chaperones during the refolding of aminoacylase. Biochem Cell Biol, v 84(1), p 30-8, 2006.

KIM, Y. S., T. W. RANDOLPH, . High-pressure studies on protein aggregates and amyloid fibrils. Methods Enzymol, v 413, p 237-53, 2006.

[

KINI, R. M. AND S. IWANAGA. Structure-function relationships of phospholipases. II: Charge density distribution and the myotoxicity of presynaptically neurotoxic phospholipases. Toxicon, v 24(9), p 895-905, 1986.

KOPITO, R. R. Biosynthesis and degradation of CFTR. Physiol Rev, v 79(1 Suppl), p S167-73, 1999.

LEE, J. C. AND S. N. TIMASHEFF The stabilization of proteins by sucrose. J Biol Chem, v 256(14): 7193-201, 1981.

LEE, S. H., J. F. CARPENTER, Effects of solutes on solubilization and refolding of proteins from inclusion bodies with high hydrostatic pressure. Protein Sci, v 15(2): 304-13, 2006.

LEFEBVRE, B. G., M. J. GAGE. "Maximizing recovery of native protein from aggregates by optimizing pressure treatment." Biotechnol Prog, v 20(2): 623-9, 2004.

LEFEBVRE, B. G. AND A. S. ROBINSON. Pressure treatment of tailspike aggregates rapidly produces on-pathway folding intermediates. Biotechnol Bioeng, v. 82(5): 595-604, 2003. 
LILIE, H., E. SCHWARZ, Advances in refolding of proteins produced in E. coli. Curr Opin Biotechnol, v 9(5): 497-501, 1998.

LOW, B. W., H. S. PRESTON,. Three dimensional structure of erabutoxin $b$ neurotoxic protein: inhibitor of acetylcholine receptor. Proc Natl Acad Sci U S A, v 73(9): 2991-4, 1976.

LU, D., Z. LIU,. Molecular dynamics for surfactant-assisted protein refolding. $\mathbf{J}$ Chem Phys, v 126(6): 064906, 2007.

MAGALHAES, G. S., M. LOPES-FERREIRA. Natterins, a new class of proteins with kininogenase activity characterized from Thalassophryne nattereri fish venom. Biochimie, v 87(8): 687-99, 2005.

MANAVALAN P., JOHNSON W.C.J., Sensitivity of circular dichroism to protein tertiary structure class. Nature, v. 305 (27), p 831-832, 1983

MIDDELBERG, A. P. Preparative protein refolding. Trends Biotechnol, v 20(10), p 437-43, 2002.

MOZHAEV, V. V., K. HEREMANS,. High pressure effects on protein structure and function. Proteins, v 24(1), p 81-91, 1996.

OHNISHI, T., K. OHNISHI,. Restoration of mutant TP53 to normal TP53 function by glycerol as a chemical chaperone. Radiat Res, v 151(4): 498-500, 1999.

OWNBY, C.L.-Structure, function and biophysical aspects of the myotoxins from snake venoms. J. Toxicol-Toxin reviews, 17 (2):213-238, 1998.

PACE, C. N., D. V. LAURENTS. pH dependence of the urea and guanidine hydrochloride denaturation of ribonuclease $A$ and ribonuclease T1. Biochemistry, v 29(10), p 2564-72, 1990.

PALADINI, A. A., JR. AND G. WEBER. Pressure-induced reversible dissociation of enolase., Biochemistry, v 20(9): 2587-93, 1981.

PATRA, A. K., R. MUKHOPADHYAY, Optimization of inclusion body solubilization and renaturation of recombinant human growth hormone from Escherichia coli. Protein Expr Purif, v 18(2): 182-92, 2000.

PEREIRA, M. F., J. C. NOVELLO, The amino acid sequence of bothropstoxin-II, an Asp-49 myotoxin from Bothrops jararacussu (Jararacucu) venom with low phospholipase A2 activity. J Protein Chem 17(4): 381-6, 1998.

PRIETO DA SILVA AR, YAMAGUSHI IK, MORAIS JF, HIGASHI HG, RAW I, HO PL, OLIVEIRA JS. Cross reactivity of different specific Micrurus antivenom sera with homologous and heterologous snake venoms, Toxiconomy, v 39, p 949-953, 2001. 
QORONFLEH, M. W., L. K. HESTERBERG, (2007). Confronting high-throughput protein refolding using high pressure and solution screens. Protein Expr Purif. 55: 209-24.

RANDOLPH, T. W., M. SEEFELDT, (2002). "High hydrostatic pressure as a tool to study protein aggregation and amyloidosis." Biochim Biophys Acta 1595(1-2): 224-34.

RICCIARDI, A., M. H. LE DU, (2000). "Do structural deviations between toxins adopting the same fold reflect functional differences?" J Biol Chem 275(24): 18302-10.

RUDOLPH, R. AND H. LILIE (1996). "In vitro folding of inclusion body proteins." FASEB J 10(1): 49-56.

SCHONER, B. E., K. S. BRAMLETT, (2005). "Reconstitution of functional nuclear receptor proteins using high pressure refolding." Mol Genet Metab 85(4): 318-22.

SEEFELDT, M. B., J. OUYANG, (2004). "High-pressure refolding of bikunin: efficacy and thermodynamics." Protein Sci 13(10): 2639-50.

SHARMA, L. AND A. SHARMA (2001). "Influence of cyclodextrin ring substituents on folding-related aggregation of bovine carbonic anhydrase." Eur $\mathbf{J}$ Biochem 268(8): 2456-63.

SILVA, J. L., Y. CORDEIRO,. (2006). "Protein folding and aggregation: two sides of the same coin in the condensation of proteins revealed by pressure studies." Biochim Biophys Acta 1764(3): 443-51.

SILVA, J. L. AND G. WEBER (1993). "Pressure stability of proteins." Annu Rev Phys Chem 44: 89-113.

SINGH, S. M. AND A. K. PANDA (2005). "Solubilization and refolding of bacterial inclusion body proteins." J Biosci Bioeng 99(4): 303-10.

SPEED, M. A., D. I. WANG, (1996). "Specific aggregation of partially folded polypeptide chains: the molecular basis of inclusion body composition." Nat Biotechnol 14(10): 1283-7.

SPENCER P.J., WEBB R., NASCIMENTO N., ROGERO J.R. SMITH L., Cloning, sequencing and expression of bothropstoxin-I, In: REUNIÃO ANUAL DA FEDERAÇÃO DE SOCIEDADES DE BIOLOGIA EXPERIMENTAL, v. 15, p 158, 2000, Caxambu, Resumos, Minas Gerais.

ST JOHN, R. J., J. F. CARPENTER, (2001). "High pressure refolding of recombinant human growth hormone from insoluble aggregates. Structural transformations, kinetic barriers, and energetics." J Biol Chem 276(50): 46856-63. 
ST JOHN, R. J., J. F. CARPENTER,. (1999). "High pressure fosters protein refolding from aggregates at high concentrations." Proc Natl Acad Sci U S A 96(23): 13029-33.

ST JOHN, R. J., J. F. CARPENTER, (2002). "High-pressure refolding of disulfidecross-linked lysozyme aggregates: thermodynamics and optimization." Biotechnol Prog 18(3): 565-71.

TSUMOTO, K., D. EJIMA,. (2003). "Practical considerations in refolding proteins from inclusion bodies." Protein Expr Purif 28(1): 1-8.

TSUMOTO, K., M. UMETSU,. (2004). "Role of arginine in protein refolding, solubilization, and purification." Biotechnol Prog 20(5): 1301-8.

VINCENTELLI, R., S. CANAAN,. (2004). "High-throughput automated refolding screening of inclusion bodies." Protein Sci 13(10): 2782-92.

YASUDA, M., Y. MURAKAMI,. (1998). "Effect of additives on refolding of a denatured protein." Biotechnol Prog 14(4): 601-6.

ZINN-JUSTIN, S., C. ROUMESTAND,. (1992). "Three-dimensional solution structure of a curaremimetic toxin from Naja nigricollis venom: a proton NMR and molecular modeling study." Biochemistry 31(46): 11335-47.

ZIPP, A. AND W. KAUZMANN (1973). "Pressure denaturation of metmyoglobin." Biochemistry 12(21): 4217-28. 